\title{
Chapter 2 \\ Patterns and Trends of Urbanization and Urban Growth in Asia
}

\author{
Graeme Hugo
}

\section{Introduction}

One of the most significant causes and consequences of the rapid social and economic transformation that has swept Asia ${ }^{1}$ in recent decades is the transition from predominantly rural to urban societies. In 1970,519 million or $24.1 \%$ of Asians were living in urban areas, but the estimates (United Nations 2014a) indicate that more than two billion Asians (46.3\%) live in urban areas in 2014. This represents not only a profound change in the population distribution but also in terms of the way Asians live their lives, work and interact. Since Asia is such a diverse and vast region, the extent and rate of urbanization has varied between countries and regions, but urbanization has been inextricably linked with those areas with the most rapidly growing economies. This chapter seeks to examine recent patterns of urbanization in Asia. In doing this, it relies upon demographic data from national censuses and data compiled by the United Nations (2014a). Accordingly, at the outset, we sound some important warnings about differentiating between urban and rural areas since the criteria vary widely between countries. An analysis is then made of changing levels of urbanization across the region, and a simple attempt is made to relate it to the level of development. A common misconception regarding urbanization in Asia is that it involves a simple redistribution of people from living in rural areas to urban

The paper 'Urban Migration Trends, Challenges, Responses and Policy in the Asia-Pacific' by author Graeme Hugo was previously published in December 2014 as one of the background papers for the 2015 World Migration Report published by the International Organization for Migration (IOM). See https://www.iom.int/sites/default/files/WMR-2015-Background-Paper-GHugo.pdf

${ }^{1}$ In this chapter, 'Asia' refers to Asia and the Pacific which is defined using the United Nations classification, including Eastern, Central, Western, Southeastern, and Southern Asia and Oceania.

G. Hugo $(\bowtie)$ (deceased)

Australian Population and Migration Research Centre, The University of Adelaide,

Adelaide, SA, Australia

K. Jayanthakumaran et al. (eds.), Internal Migration, Urbanization, and Poverty

in Asia: Dynamics and Interrelationships,

https://doi.org/10.1007/978-981-13-1537-4_2 
areas. It is demonstrated here that the process is a much more complex one involving a mix of migration and mobility strategies. A closer examination is made then of the dynamics of population growth in urban Asia. Finally, some comments are made regarding future patterns of urbanization in the region.

\section{Defining Urban Areas in Asia and the Pacific}

There is little argument that the rural-urban divide is the most significant economic and social distinction. However, the reality is that over recent decades, there has been a blurring of the distinction between the rural and the urban and nowhere has this been more marked than in the Asian region. A number of processes have contributed to the difficulty in distinguishing between:

(a) Rural and urban areas

(b) Rural and urban populations

This is related to two major considerations that have led to considerable debate as to the extent to which official urban population figures accurately depict the actual urban populations (Jones and Douglass 2008; Zhu 1999):

(a) The failure of boundaries of urban areas (especially the megacities) to reflect accurately either the extent of built-up areas or the functional urban or metropolitan areas that constitute their effective labour market (Champion and Hugo 2004). These boundaries tend to lower urban centres and lead to significant underestimates of urban, especially metropolitan, populations, which rapidly expand laterally and swallow up adjacent urban areas.

(b) The fact that there are millions of residents of the People's Republic of China (PRC) and ASEAN (Association of Southeast Asian Nations) countries whose official residence is in rural areas or small towns and their families reside fulltime there but who earn much of their living and spend much of their lives in large cities through circular migration or commuting strategies, this means that official figures on urban populations understate the functional urban populations (Hugo 1978, 1982; Jun 2010; Tie 2010).

The latter point is especially important. In most nations, especially the larger ones, one can distinguish between a permanently settled resident population and a temporarily present group of 'circular migrants' from the outside. However, there are two things that distinguish the situation in the PRC from that in other ASEAN megacities:

(a) First, the massive size of the circular migrant worker population. In 2008, such migrants in the PRC numbered 225 million, of whom 140 million worked in urban areas outside of their home communities (Jun 2010). This means that migrant workers make for around one in four urban residents, although the proportion is higher in some large cities. Moreover, these migrants contribute to 
a large part of the rapid population increase in the PRC's cities. Tie (2010) has indicated that $38.1 \%$ of the 420 million population increase in the PRC's urban population between 1978 and 2007 was accounted for by the influx of rural migrant workers. In 2006, a survey of 2799 villagers by the Development Research Centre of the State Council found that $18.1 \%$ of all rural workers had migrated to do long-term off-farm jobs.

(b) Second, the differentiation between the resident population and migrant workers is institutionalized through the hukou system. People are registered in their home area, and it is difficult to transfer hukou, especially from rural to large urban areas. Accordingly, there are important differences in access to services in cities between residents with home hukou and migrant workers who still have a rural farmer hukou.

Jones (2004), in examining these issues, concludes that the recorded statistical increase in urbanization fails to capture what has really been going on. The key point here is that UN and other data in most countries in Asia considerably underestimate the scale and impact of urbanization because they define urban in traditional terms which fail to take account of the 'new mobility in Asia'.

A second definitional issue to bear in mind relates to the massive differences between Asian nations in the ways in which they define urban areas. Many countries simply use an administrative boundary, which may or may not coincide with intrinsically urban population occupied areas. Others use more functional definitions based on population density, income, type of economic activity, availability of facilities and so on. Jones (2004) demonstrates the impact of this factor by comparing the Philippines and Thailand. An updated version of his table is provided in Table 2.1. Jones shows that due to the quite different urban definitions used in the

Table 2.1 Comparison of the Philippines and Thailand: development indicators and level of urbanization

\begin{tabular}{|c|c|c|c|c|c|c|}
\hline & 1960 & 1970 & 1980 & 1990 & 2000 & 2014 \\
\hline \multicolumn{7}{|l|}{ Per capita income } \\
\hline Philippines & 295 & 410 & 690 & 730 & 1040 & 2765 \\
\hline Thailand & 200 & 380 & 670 & 1570 & 2010 & 5779 \\
\hline \multicolumn{7}{|c|}{$\%$ male employment in agriculture } \\
\hline Philippines & 59 & 57 & 62 & 53 & 47 & 39 \\
\hline Thailand & 78 & 75 & 72 & 64 & $56^{\mathrm{a}}$ & 41 \\
\hline \multicolumn{7}{|l|}{$\%$ urban } \\
\hline Philippines & 30.3 & 33.0 & 37.5 & 48.8 & 58.6 & 44.5 \\
\hline Thailand & 12.5 & 13.3 & 17.0 & 18.7 & 31.1 & 49.2 \\
\hline Difference in $\%$ urban & 17.8 & 19.7 & 20.5 & 30.1 & 27.3 & 4.7 \\
\hline
\end{tabular}

Sources: Jones 2004; United Nations 2014a; World Bank, World Development Indicators, online data

Notes: Per capita income for 1970 is actually for 1976, for 1990 actually 1991 and for 2014 actually 2013

${ }^{\mathrm{a}}$ Both males and females 
censuses of the two countries, there has been a massive underestimation of Thai urban populations and an exaggeration of that of the Philippines.

Table 2.1 shows that urban percentage between the Philippines and Thailand has been widening prior to 2000. Thailand's urban percentage was much lower than the Philippines. Even though Thailand's economic development was faster than that of the Philippines, this does not reflect in the urbanization statistics. Therefore, some care needs to be exercised in interpreting the trends in urban growth and urbanization in Asia, which are described subsequently.

\section{The Pace of Urbanization}

In examining the rural to urban transition in Asia, there are two key dimensions that need to be considered. Urbanization is defined as the percentage of the national population living in urban areas. In the Asian context, however, it is also important to examine the second dimension-urban growth. This refers to the numbers of national citizens living in urban areas, and in Asia, there has been a massive growth in the numbers living in urban areas, while in several countries rural populations have begun to decline.

The tempo of urbanization in Asia since 1950 and projected through to 2050 is presented in Fig. 2.1, which also shows patterns for some key Asian countries as well as global patterns. Notwithstanding the data issues, this shows that there has been a large increase in the proportion of Asians living in urban areas, with the $50 \%$ threshold to be passed in 2020. While the graph for the more developed countries (MDCs) increased in the 1950s-1970s, it has subsequently increased more slowly. Most striking in Fig. 2.1, however, is the PRC. In 1950, the PRC had the lowest level of urbanization of all the jurisdictions shown in the diagram. However, it increased rapidly during the 1990s and 2000s and is projected to continue to increase rapidly so that by 2050 it would approach the level of urbanization in the MDCs. India, on the other hand, had higher levels of urbanization than the PRC up to 1985 but subsequently experienced more modest growth in urbanization, although the UN projections suggest there will be an increase in tempo over the next three decades. The patterns for ASEAN countries are also shown in Fig. 2.1 and indicate a strong consistent pattern of increase over the 100 years shown, which will see their level of urbanization increase from $15 \%$ to over $60 \%$ by 2050 .

Figure 2.2 shows the levels of urbanization for selected economies for the selected years 1950, 2014 and 2050. While some variations from the rapid urbanization shown for regions in Fig. 2.1 are apparent, in some areas, there are clearly some definitional issues. At one end, Hong Kong, China; Macau, China; and Singapore represent one extreme, but there are a number of economies with less than a third of their population in urban areas in 2014. Sri Lanka, with $18.3 \%$ urban, is clearly a case with an urban definition that fails to include its functional urban population. However, most of these economies have low incomes and are lagging in development compared to many Asian economies. Several of these economies have suffered 


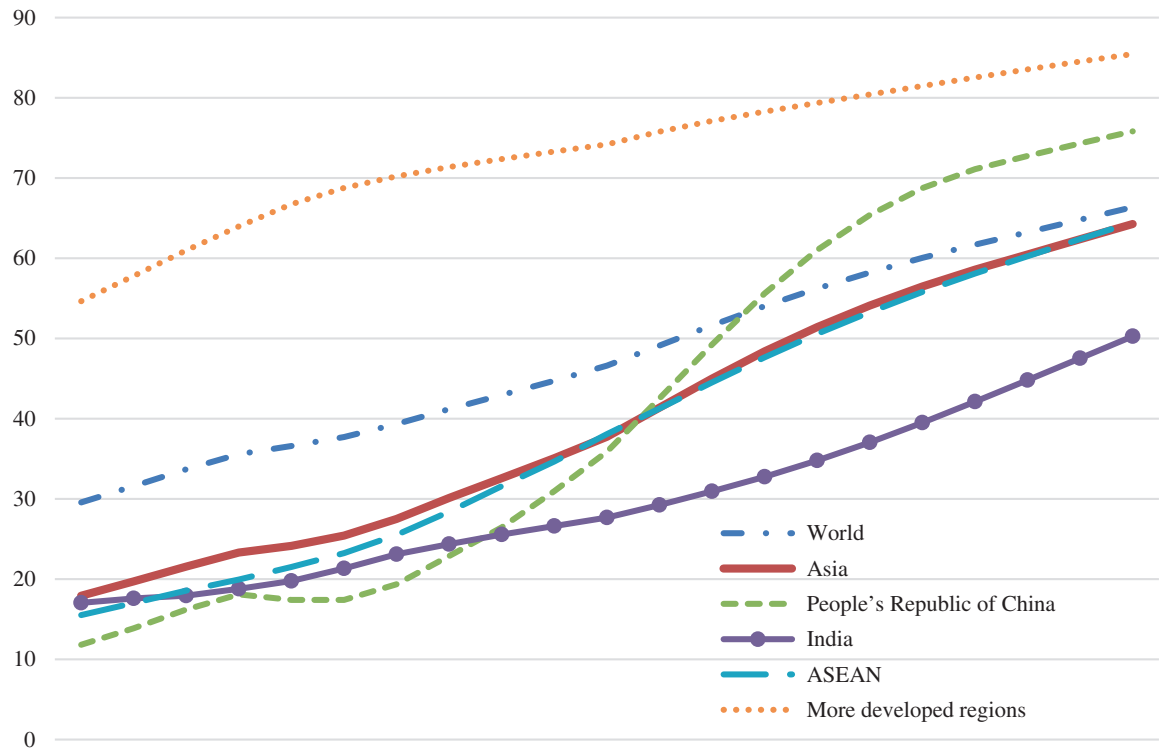

195019551960196519701975198019851990199520002005201020152020202520302035204020452050

Fig. 2.1 Selected regions: percentage of the population in urban areas, 1950 to projected 2010 2050. (Source: United Nations 2014a)

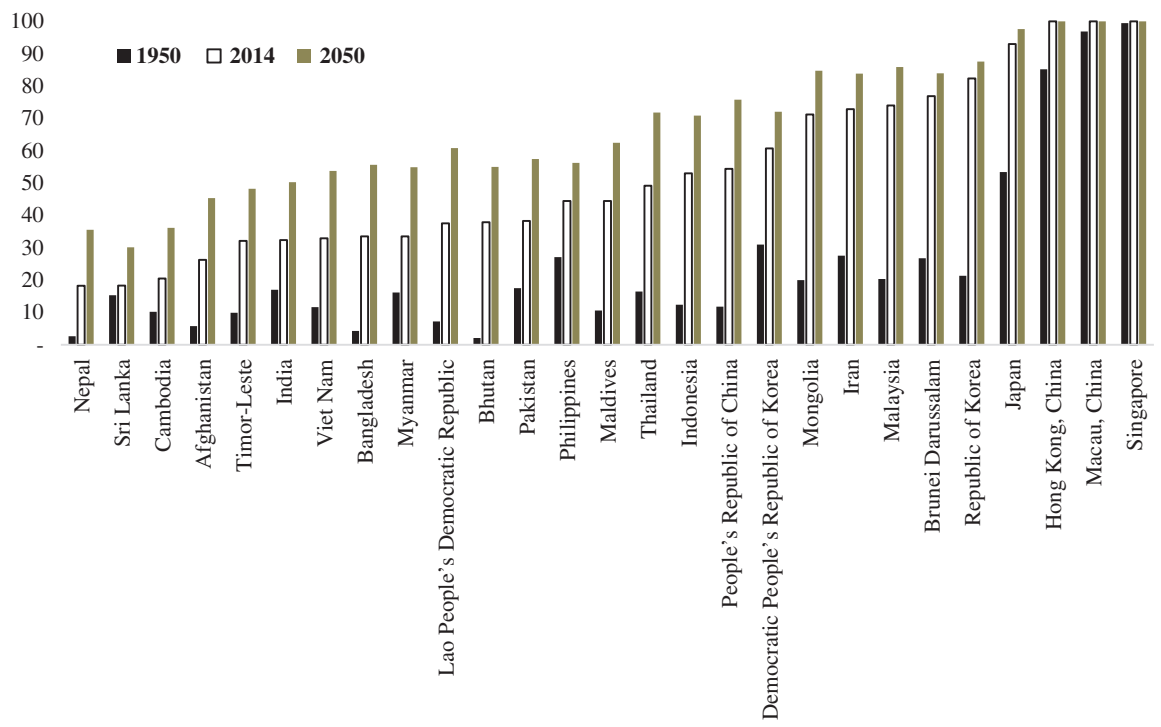

Fig. 2.2 Selected Asian economies: percentage urban by economy, 1950, 2014 and 2050. (Source: United Nations 2014a) 
prolonged conflicts, which clearly have delayed development and urbanization such as Cambodia (20.5\%), Afghanistan (26.3\%), Timor-Leste (32.1\%) and Viet Nam (33\%). However, some of the poorest economies in Asia are included here-Nepal (18.2\%), Bangladesh (33.5\%) and Myanmar (33.6\%).

It is notable in Fig. 2.2, however, that many Asian economies had passed the 50\% threshold in 2014, whereby the majority of their populations lived in urban areas. This of course includes the 'tiger' economies of the 1980s and 1990s but also some of the largest economies in the region (PRC [54.4\%] and Indonesia [53\%]). The
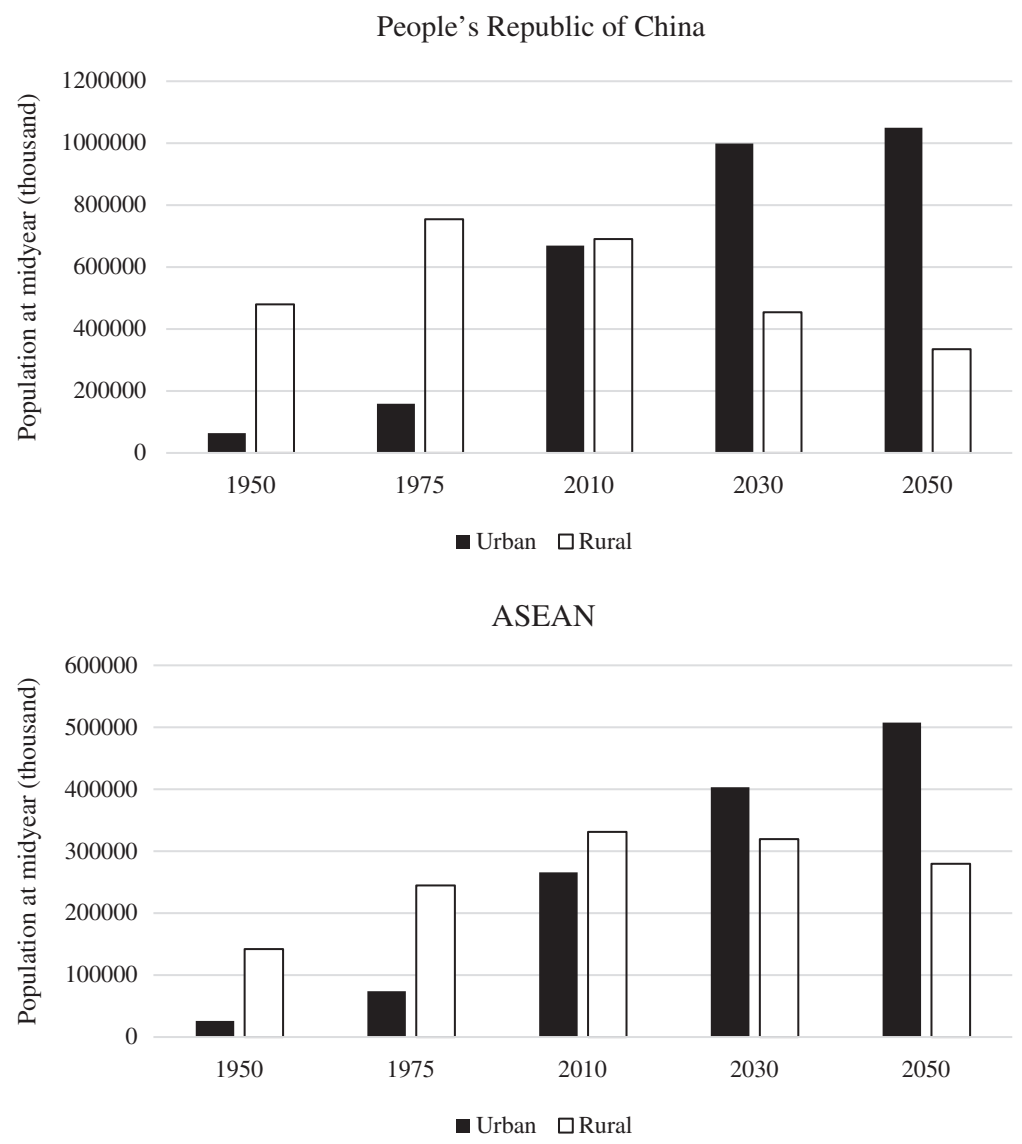

Fig. 2.3 Asia: urban and rural population by region, 1950-2050. (Source: United Nations 2014a) 


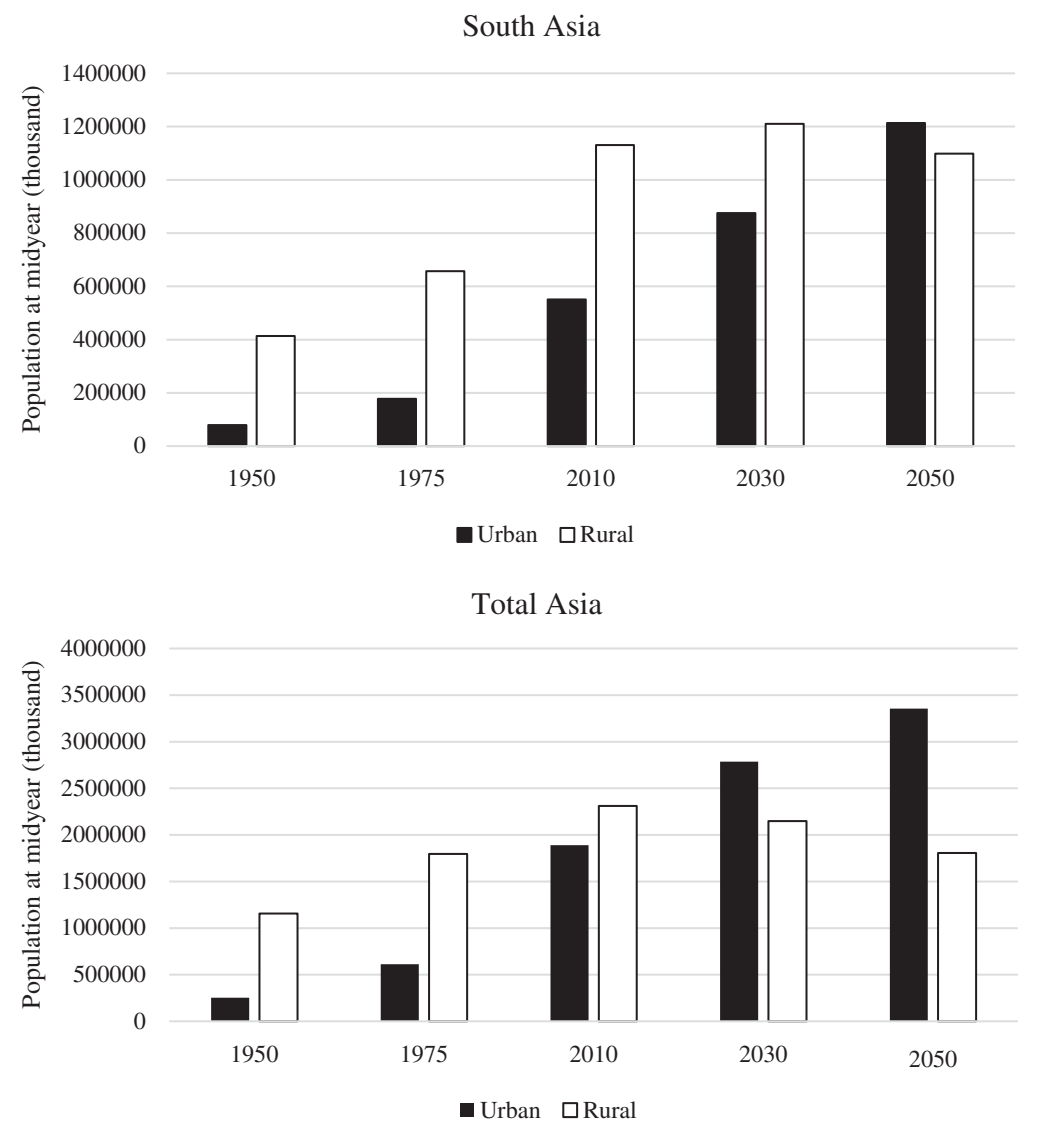

Fig. 2.3 (continued)

Thailand/Philippines anomaly noted by Jones (2004) is still in evidence. A strong pattern of lower urbanization in South Asia than East Asia, with Southeast Asia lying in between, is apparent. Low levels of urbanization in 2014 were evident in each South Asian economy-India (32.4\%), Pakistan (38.3\%) and Bangladesh $(33.5 \%)$.

Much of the discussion on the urban transition in Asia examines only the percentage of national populations living in urban areas, but it is important also to focus on the numbers of people involved since this gives a more striking perspective on the challenges being faced in urban Asia, especially the largest cities. Accordingly, we have shown in Fig. 2.3 the changes in the rural and urban population sizes in key 


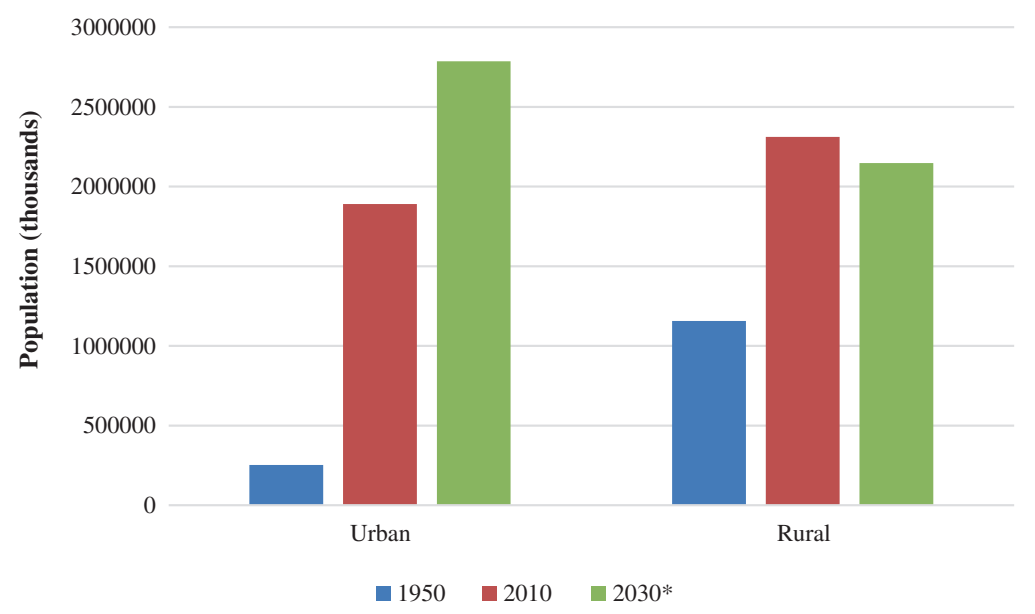

Fig. 2.4 Urban and rural population in Asia, 1950, 2010 and 2030. (Source: United Nations 2014a). Note: $*$ projections

Asian regions over the 1950-2050 period. The patterns depicted here are very striking. It is apparent that not only in 1950 but also in 1975, Asia was overwhelmingly a rural society and economy, with rural populations being clearly dominant. Thereafter, there have been dramatic changes with exponential growth of urban populations and a concomitant decline in rural population, although timing has differed between different regions.

Figure 2.4 shows the massive urban growth that occurred in the Asian urban sector between 1950 and 2010 (from 252 million to almost 1.9 billion people), while the rural population increased from 1.2 to 2.3 billion. On the other hand, the Asian rural population is expected to decline over the next two decades, while the urban population will increase. While reclassification of areas from rural to urban status has been of major significance, the main reason for faster population growth in urban areas has been rural-urban migration.

However, the overall Asia data has enormous variations between economies. Table 2.2 shows that South Asia is the least urbanized part of the region with less than a third (32.7\%) of its population living in urban areas, while East Asia is the most urbanized (54.3\%). By 2030, more than two in three residents in East Asia will live in urban areas, while the urban proportion will be $42 \%$ in South Asia and 55.8\% in Southeast Asia. The variation is even greater between individual economies with the level of urbanization varying from economies of Hong Kong, China and Singapore to the rural economies of Timor-Leste (29.5\% living in urban areas) and Bhutan (34.8\%) in 2010. It is especially important to consider trends in the largest economies. Of the 10 economies with more than 100 million residents in 2000, 6 were in Asia. Table 2.3 shows trends in growth of the urban populations in these economies. 
Table 2.2 Urban population in Asia, number and percentage estimates, 1950 to 2010, and 2030*

\begin{tabular}{|c|c|c|c|c|c|c|c|c|}
\hline \multirow[b]{2}{*}{ Region } & \multicolumn{2}{|l|}{1950} & \multicolumn{2}{|l|}{2000} & \multicolumn{2}{|l|}{2010} & \multicolumn{2}{|l|}{$2030 *$} \\
\hline & No. ('000) & $\%$ & No. ('000) & $\%$ & No. ('000) & $\%$ & No. ('000) & $\%$ \\
\hline Eastern Asia & 119,111 & 17.9 & 632,396 & 42.0 & 865,826 & 54.3 & $1,207,794$ & 71.5 \\
\hline Central Asia & 5715 & 32.7 & 22,870 & 41.5 & 24,951 & 40.4 & 34,020 & 44.1 \\
\hline Southern Asia & 78,950 & 16.0 & 420,685 & 29.1 & 550,607 & 32.7 & 875,188 & 42.0 \\
\hline Southeastern Asia & 26,066 & 15.5 & 199,681 & 38.1 & 265,801 & 44.5 & 403,284 & 55.8 \\
\hline Western Asia & 14,732 & 28.8 & 117,108 & 63.8 & 157,652 & 68.1 & 232,170 & 74.1 \\
\hline Oceania & 7906 & 62.4 & 22,013 & 70.5 & 25,924 & 70.7 & 33,747 & 71.3 \\
\hline Asia & 252,480 & 17.9 & $1,414,753$ & 37.7 & $1,890,760$ & 45.0 & $2,786,204$ & 56.5 \\
\hline
\end{tabular}

Source: United Nations (2014a)

Note: $*$ projections

Table 2.3 Asia's largest countries: urban population, number and percentage estimates, 1950 and 2000 and 2030*

\begin{tabular}{l|l|l|l|l|l|l|l|l}
\hline \multirow{2}{*}{} & \multicolumn{3}{|l}{1950} & \multicolumn{2}{l}{2000} & \multicolumn{2}{l}{ 2030* } \\
\cline { 2 - 10 } & No. ('000) & $\%$ & $\begin{array}{l}\text { \% Growth } \\
1950-2000\end{array}$ & No. ('000) & $\%$ & $\begin{array}{l}\text { Growth } \\
1950-2030\end{array}$ & No. ('000) & $\%$ \\
\hline PRC & 64,180 & 11.8 & 615.8 & 459,383 & 35.9 & 117.4 & 998,925 & 68.7 \\
\hline India & 64,134 & 17.0 & 349.6 & 288,365 & 27.7 & 102.2 & 583,038 & 39.5 \\
\hline Indonesia & 9001 & 12.4 & 874.9 & 87,759 & 42.0 & 110.7 & 184,912 & 63.0 \\
\hline Pakistan & 6578 & 17.5 & 625.0 & 47,687 & 33.2 & 126.2 & 107,880 & 46.6 \\
\hline Bangladesh & 1623 & 4.3 & 1824.6 & 31,230 & 23.6 & 166.3 & 83,160 & 44.9 \\
\hline Japan & 43,896 & 53.4 & 125.2 & 98,873 & 78.6 & 18.3 & 116,918 & 96.9 \\
\hline
\end{tabular}

Source: United Nations (2014a)

Note: PRC People's Republic of China; * = projections

Clearly, there has been massive urban growth over the 1950-2000 period, and this will at least double again except in Japan and the PRC. Only Japan had more than half of its population in urban areas in 2000, but by 2030 this will also be the case in the PRC and Indonesia. It is also important to consider the tempo of change in urbanization and urban growth.

In net growth terms, urban areas of Asia and Africa will absorb almost all of the world's net population growth over the period up to 2050. Around $90 \%$ of the 2.5 million urban dwellers added to the global population will live in Asia and Africa. One of the clear differences between Asia and Africa, however, is depicted in Fig. 2.5-while half of the Asian countries are experiencing a decline in their rural populations, both urban and rural populations are increasing in Africa. UN projections indicate that two-thirds of countries will experience decreases in their rural populations between 2014 and 2050, including most countries in Asia (United Nations 2014b, 3). 


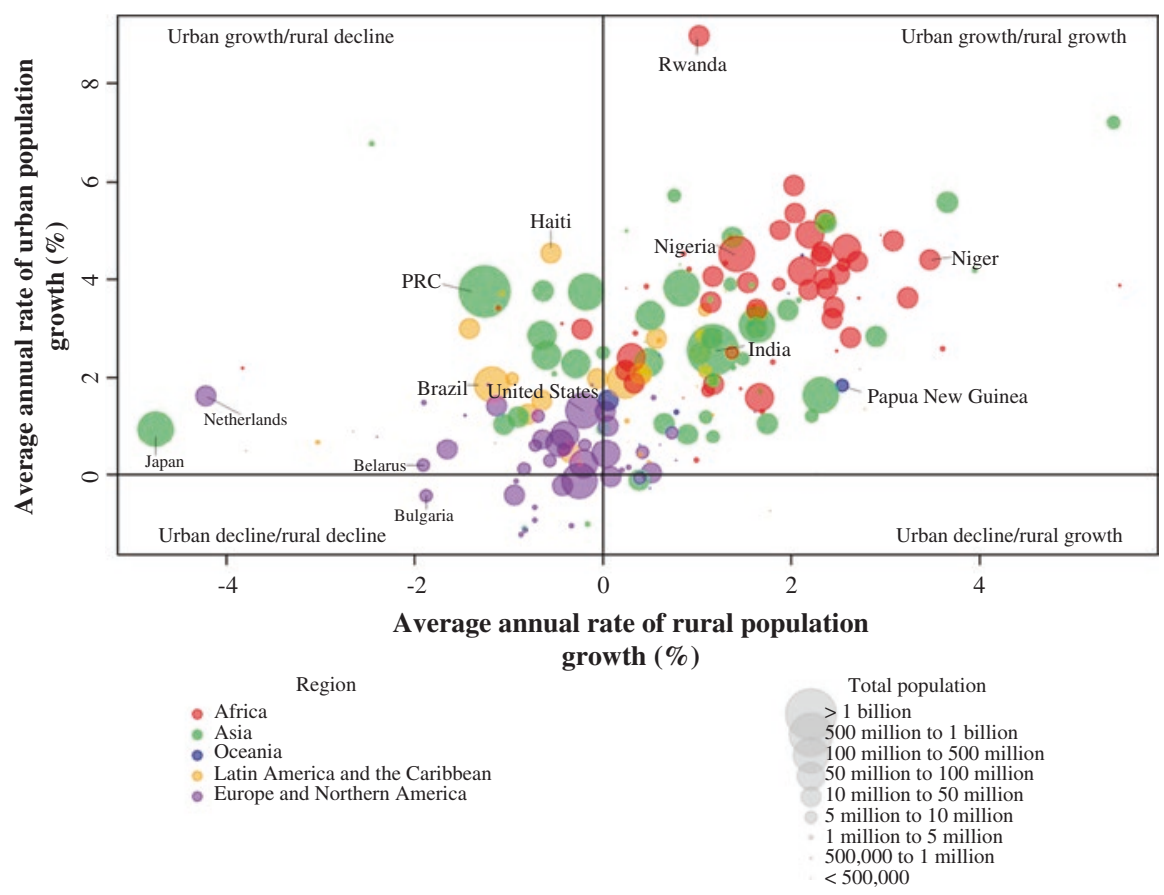

Fig. 2.5 Average annual rates of urban and rural population growth, 1990-2014. (Source: United Nations 2014b, 4)

Note: 201 countries or areas with at least 90,000 inhabitants in 2014; PRC People's Republic of China

\section{Patterns of Urbanization}

The processes of urbanization and urban growth have been fundamental elements in Asia's economic 'miracle'. Asia's percentage of urban share remains at 47.5 in 2014 (UN 2014a). However, this has, by no means, been a uniform process across Asia. Table 2.4 shows how the level of urbanization varied widely across Asia in 2014. The broad pattern of high levels of urbanization in East Asia, low in South Asia and with Southeast Asia falling between them is in evidence.

There are important linkages between urbanization, on the one hand, and economic development and poverty reduction, on the other. While the data (especially that on the level of urbanization) is compromised in a number of economies, Fig. 2.6 shows that there is a clear correlation in Asia between level of urbanization and GDP per capita. 'Location' is important at all stages of development, but it is especially significant in poorer and developing economies (World Bank and IMF 2013, 85). It is apparent, however, that not only are there wide disparities between rural and urban areas in development and living standards, but also processes associated with urbanization have an impact upon national development.

Turning to the linkages between urbanization and poverty, there are a number of global generalizations which are emerging: 
Table 2.4 Percentage urban by economy, 2014

\begin{tabular}{|c|c|c|c|}
\hline & Percentage urban & & Percentage urban \\
\hline Eastern Asia & 58.9 & Western Asia & 69.6 \\
\hline $\begin{array}{l}\text { China, People's } \\
\text { Republic of }\end{array}$ & 54.4 & Armenia & 62.8 \\
\hline Hong Kong, China & 100.0 & Azerbaijan & 54.4 \\
\hline Macau, China & 100.0 & Bahrain & 88.7 \\
\hline $\begin{array}{l}\text { Korea, Democratic } \\
\text { People's Republic of }\end{array}$ & 60.7 & Cyprus & 67.0 \\
\hline Korea, Republic of & 82.4 & Georgia & 53.5 \\
\hline Japan & 93.0 & Iraq & 69.4 \\
\hline Mongolia & 71.2 & Israel & 92.1 \\
\hline \multirow[t]{2}{*}{ Other non-specified areas } & 76.5 & Jordan & 83.4 \\
\hline & & Kuwait & 98.3 \\
\hline Central Asia & 40.4 & Lebanon & 87.7 \\
\hline Kazakhstan & 53.3 & State of Palestine & 75.0 \\
\hline Kyrgyz Republic & 35.6 & Oman & 77.2 \\
\hline Tajikistan & 26.7 & Qatar & 99.2 \\
\hline Turkmenistan & 49.7 & Saudi Arabia & 82.9 \\
\hline \multirow{2}{*}{ Uzbekistan } & 36.3 & Syrian Arab Republic & 57.3 \\
\hline & & Turkey & 72.9 \\
\hline Southern Asia & 34.4 & United Arab Emirates & 85.3 \\
\hline Afghanistan & 26.3 & Yemen & 34.0 \\
\hline Bangladesh & 33.5 & & \\
\hline Bhutan & 37.9 & Oceania & 70.8 \\
\hline India & 32.4 & Australia & 89.3 \\
\hline Iran (Islamic Republic of) & 72.9 & New Zealand & 86.3 \\
\hline Maldives & 44.5 & Fiji & 53.4 \\
\hline Nepal & 18.2 & New Caledonia & 69.7 \\
\hline Pakistan & 38.3 & Papua New Guinea & 13.0 \\
\hline \multirow{2}{*}{ Sri Lanka } & 18.3 & Solomon Islands & 21.9 \\
\hline & & Vanuatu & 25.8 \\
\hline Southeastern Asia & 47.0 & Guam & 94.4 \\
\hline Brunei Darussalam & 76.9 & Kiribati & 44.2 \\
\hline Cambodia & 20.5 & Marshall Islands & 72.4 \\
\hline Indonesia & 53.0 & Micronesia, Fed. States of & 22.4 \\
\hline $\begin{array}{l}\text { Lao People's Democratic } \\
\text { Republic }\end{array}$ & 37.6 & Nauru & 100.0 \\
\hline Malaysia & 74.0 & Northern Mariana Islands & 89.3 \\
\hline Myanmar & 33.6 & Palau & 86.5 \\
\hline Philippines & 44.5 & American Samoa & 87.3 \\
\hline Singapore & 100.0 & Cook Islands & 74.3 \\
\hline Thailand & 49.2 & French Polynesia & 56.0 \\
\hline Timor-Leste & 32.1 & Niue & 41.8 \\
\hline \multirow[t]{5}{*}{ Viet Nam } & 33.0 & Samoa & 19.3 \\
\hline & & Tokelau & 0 \\
\hline & & Tonga & 23.6 \\
\hline & & Tuvalu & 58.8 \\
\hline & & Wallis and Futuna Islands & 0 \\
\hline
\end{tabular}

Source: United Nations (2014a) 


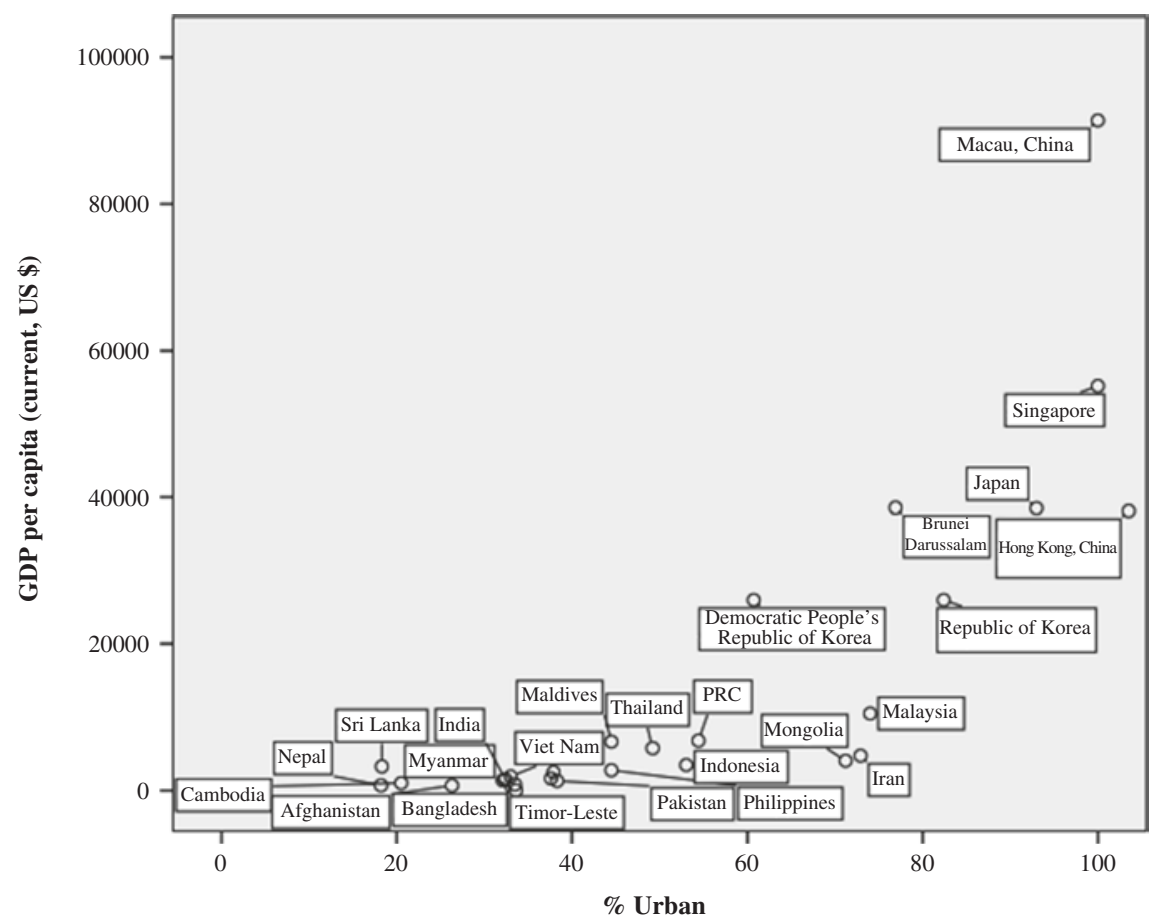

Fig. 2.6 Asia: level of urbanization 2014 and GDP per capita 2013 (current US \$). (Source: United Nations 2014a; World Bank 2014)

Note: PRC People's Republic of China

- Poverty rates are falling in both rural and urban areas.

- Poverty rates are significantly lower in urban than rural areas.

- With the growth in urban and decline in rural populations, poverty is becoming an increasingly urban issue in Asia.

Table 2.5 shows that South Asia had substantially higher poverty rates than the remainder of Asia and that poverty is high in both rural and urban areas. Moreover, it is evident from the table how the differential between urban and rural poverty rates persisted between 1990 and 2008. There was, however, a striking change in East Asia over the period. In 1990, there were almost 1 billion people in poverty, but by 2008 this had been more than halved. The declines in poverty rates are spectacular, with rural rates declining from $67.5 \%$ in 1990 to $20.4 \%$ in 2008 . Even more striking is the decline in urban poverty rates from $24.4 \%$ to $4.3 \%$.

Recent research (World Bank and IMF 2013) suggests that there are 'poverty city size gradients', whereby there is a relationship between the size of a place and the rate of poverty. Poverty tends to be lowest in the largest cities and higher in small cities and towns. The World Bank and IMF (2013) point out:

Despite their megacities and sprawling slums, urban poverty in South and East Asia is firmly located in smaller towns, not in big cities. 


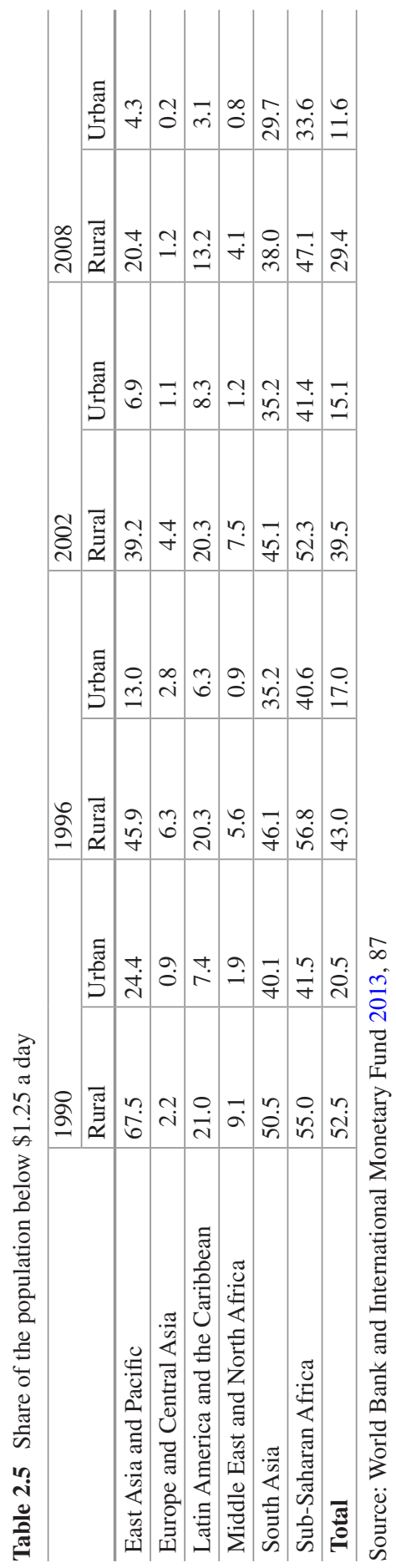




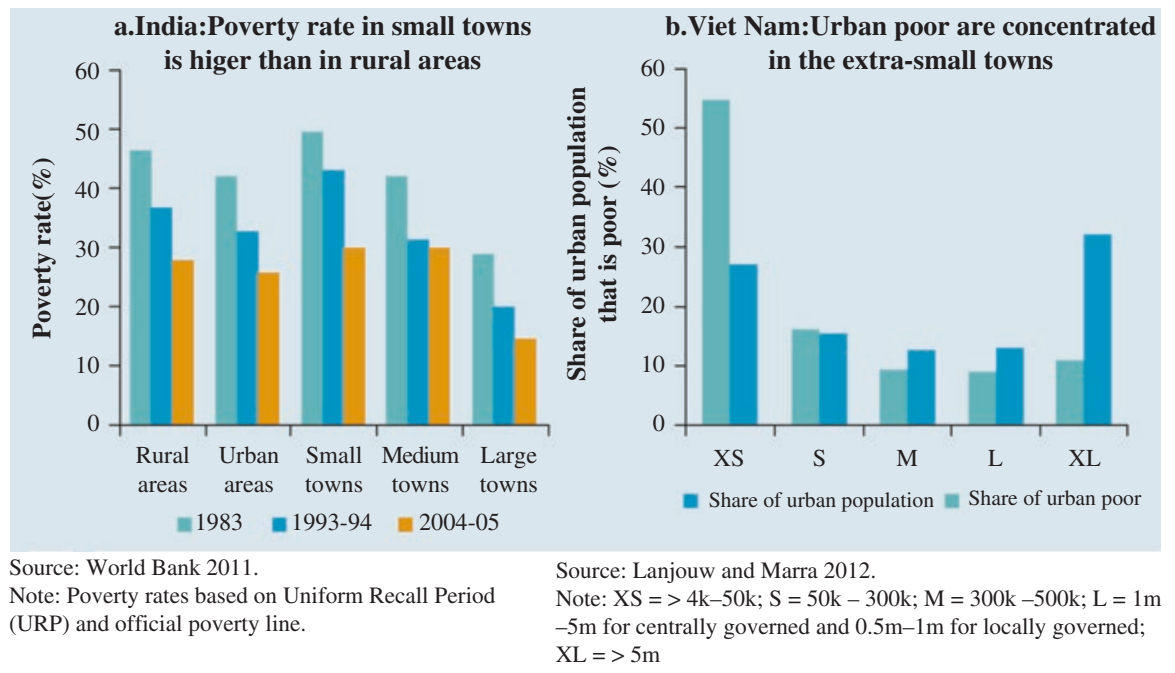

Fig. 2.7 In India and Viet Nam, poverty in small towns is worse than in large cities. (Source: World Bank and International Monetary Fund 2013, 91)

They present two examples to demonstrate this relationship. Figure 2.7 shows patterns for India and Viet Nam, which show that poverty is greater in smaller towns than cities. In India, for example, research in 2004-2005 found that the poverty rate was $28 \%$ in rural areas and 26\% in urban areas. However, in Indian urban areas, poverty rates in towns (population less than 50,000) double those in cities with one million or more residents (Lanjouw and Marra 2012; World Bank 2011). In Pakistan and Bangladesh, the incidence of poverty is highest in rural areas (43\%), followed by smaller towns and cities (38\%) and then metropolitan areas (26\%) (Deichmann et al. 2009).

The Viet Nam example in Fig. 2.7 shows an interesting U-shaped pattern. The two largest cities in the country (Ha Noi and Ho Chi Minh City) have nearly a third of Viet Nam's urban population but only a tenth of the national population in poverty. However, 55\% of the urban poor live in the 634 smallest towns (World Bank and IMF 2013, 90).

Much attention has been focused on the emergence of megacities in Asia—urban agglomerations with populations of ten million or more residents. They are complex cities of a scale and complexity not previously seen, often multinuclear in that they have enveloped smaller cities in their lateral spread. A key feature of Asian megacities is the fact that they include extensive peri-urban regions of mixed urban and rural land use but which are heavily tied to the urban area by commuting and other linkages (Jones 2004). However, UN data on megacities usually applies to areas defined by city boundaries. In megacities, the built-up area usually overspills these boundaries, and the definition also excludes the large peri-urban development. A decade ago, Hugo (2004) showed that while the United Nations estimated the Jakarta megacity population at 11.4 million, the real functioning population of the megacity at that time was 20.2 million. Jones and Douglass (2008) have demonstrated this systematic underestimation of the size of Asian megacities in censuses 
Table 2.6 Population and growth rate of urban agglomerations with more than ten million inhabitants in 2014, 1975 to 2030

\begin{tabular}{|c|c|c|c|c|c|c|c|}
\hline \multirow[b]{2}{*}{ Urban agglomeration } & \multicolumn{4}{|c|}{ Population ('000) } & \multicolumn{3}{|c|}{ Growth rate $(\%)$} \\
\hline & 1975 & 2000 & 2015 & 2030 & $\begin{array}{l}1975- \\
2000\end{array}$ & $\begin{array}{l}2000- \\
2015\end{array}$ & $\begin{array}{l}2015- \\
2030\end{array}$ \\
\hline Tokyo & 26,615 & 34,450 & 38,001 & 37,190 & 1.04 & 0.66 & -0.14 \\
\hline Delhi & 4,426 & 15,732 & 25,703 & 36,060 & 5.20 & 3.33 & 2.28 \\
\hline Shanghai & 5,627 & 13,959 & 23,741 & 30,751 & 3.70 & 3.60 & 1.74 \\
\hline $\begin{array}{l}\text { Ciudad de México (Mexico } \\
\text { City) }\end{array}$ & 10,734 & 18,457 & 20,999 & 23,865 & 2.19 & 0.86 & 0.86 \\
\hline São Paulo & 9,614 & 17,014 & 21,066 & 23,444 & 2.31 & 1.43 & 0.72 \\
\hline Mumbai (Bombay) & 7,082 & 16,367 & 21,043 & 27,797 & 3.41 & 1.69 & 1.87 \\
\hline Kinki M.M.A. (Osaka) & 16,298 & 18,660 & 20,238 & 19,976 & 0.54 & 0.54 & -0.09 \\
\hline Beijing & 4,828 & 10,162 & 20,384 & 27,706 & 3.02 & 4.75 & 2.07 \\
\hline New York-Newark & 15,880 & 17,813 & 18,593 & 19,885 & 0.46 & 0.29 & 0.45 \\
\hline Al-Qahirah (Cairo) & 6,450 & 13,626 & 18,772 & 24,502 & 3.04 & 2.16 & 1.79 \\
\hline Dhaka & 2,221 & 10,285 & 17,598 & 27,374 & 6.32 & 3.65 & 2.99 \\
\hline Karachi & 3,989 & 10,032 & 16,618 & 24,838 & 3.76 & 3.42 & 2.72 \\
\hline Buenos Aires & 8,745 & 12,407 & 15,180 & 16,956 & 1.41 & 1.35 & 0.74 \\
\hline Kolkata (Calcutta) & 7,888 & 13,058 & 14,865 & 19,092 & 2.04 & 0.87 & 1.68 \\
\hline Istanbul & 3,600 & 8,744 & 14,164 & 16,694 & 3.61 & 3.27 & 1.10 \\
\hline Chongqing & 2,545 & 7,863 & 13,332 & 17,380 & 4.62 & 3.58 & 1.78 \\
\hline Rio de Janeiro & 7,733 & 11,307 & 12,902 & 14,174 & 1.53 & 0.88 & 0.63 \\
\hline Manila & 4,999 & 9,962 & 12,946 & 16,756 & 2.80 & 1.76 & 1.73 \\
\hline Lagos & 1,890 & 7,281 & 13,123 & 24,239 & 5.54 & 4.01 & 4.18 \\
\hline $\begin{array}{l}\text { Los Angeles-Long } \\
\text { Beach-Santa Ana }\end{array}$ & 8,926 & 11,798 & 12,310 & 13,257 & 1.12 & 0.28 & 0.50 \\
\hline Moskva (Moscow) & 7,623 & 10,005 & 12,166 & 12,200 & 1.09 & 1.31 & 0.02 \\
\hline Guangzhou, Guangdong & 1,698 & 7,330 & 12,458 & 17,574 & 6.02 & 3.60 & 2.32 \\
\hline Kinshasa & 1,482 & 6,140 & 11,587 & 19,996 & 5.85 & 4.32 & 3.70 \\
\hline Tianjin & 3,527 & 6,670 & 11,210 & 14,655 & 2.58 & 3.52 & 1.80 \\
\hline Paris & 8,558 & 9,737 & 10,843 & 11,803 & 0.52 & 0.72 & 0.57 \\
\hline Shenzhen & 36 & 6,550 & 10,749 & 12,673 & 23.20 & 3.36 & 1.10 \\
\hline London & 7,546 & 8,613 & 10,313 & 11,467 & 0.53 & 1.21 & 0.71 \\
\hline Jakarta & 4,813 & 8,390 & 10,323 & 13,812 & 2.25 & 1.39 & 1.96 \\
\hline
\end{tabular}

Source: United Nations (2014a)

Note: Urban agglomerations are ordered according to their population in size in 2014

and the United Nations figures. The concept of the megacity has challenged traditional methods of defining the boundaries of urban areas. Hence, although Table 2.6 shows a slowdown in the growth rate of Asian megacity populations over the next 15 years, these rates and the population sizes for several countries have to be questioned. The significance of 'mega-urban' regions in the world is seen from the fact that Jones (2002) had estimated a decade ago that $11 \%$ of the total population of Southeast Asia is living in such regions.

Putting aside the definition problems of megacities, Table 2.7 shows the past, current and future global situation according to United Nations' calculations. One 


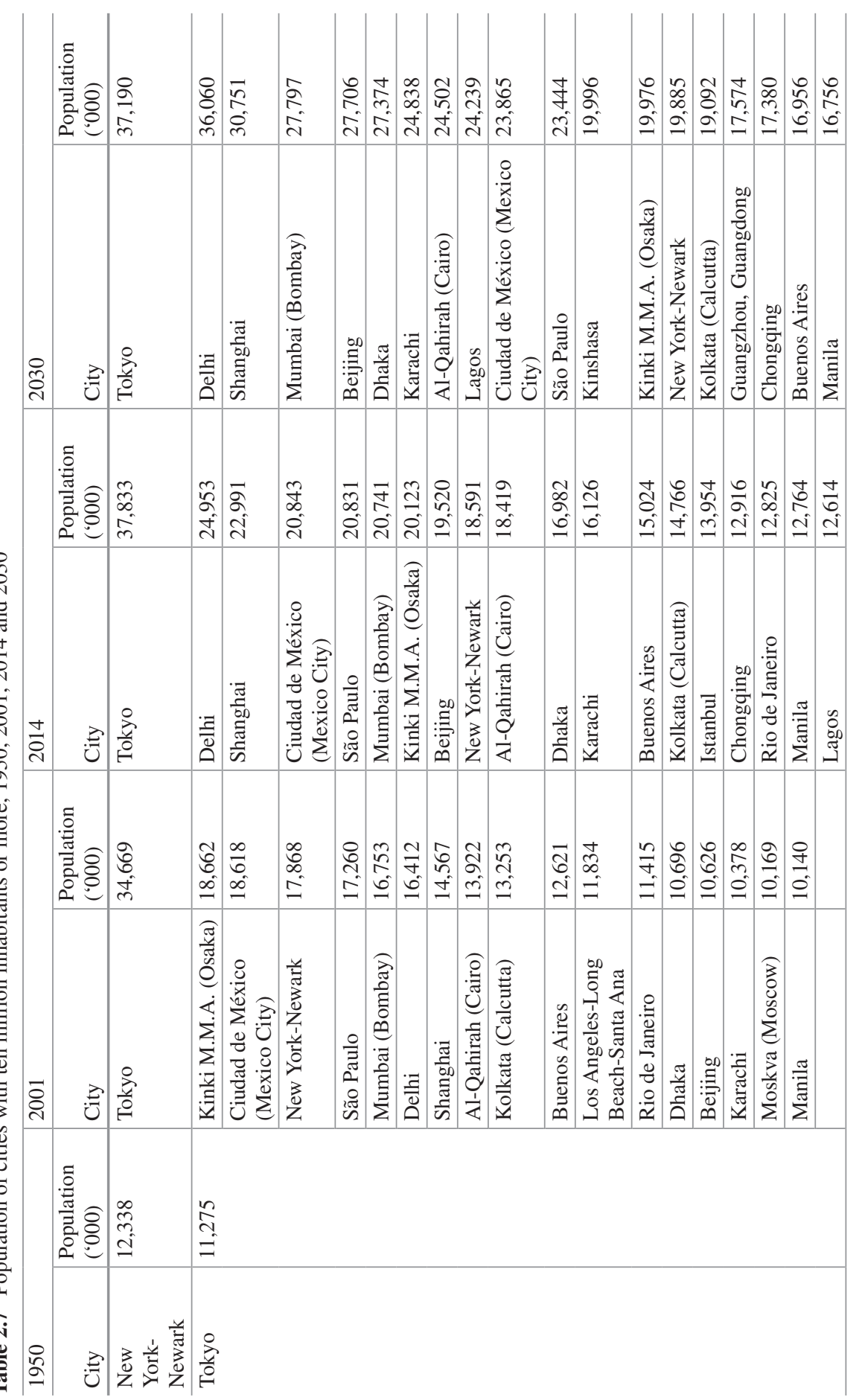




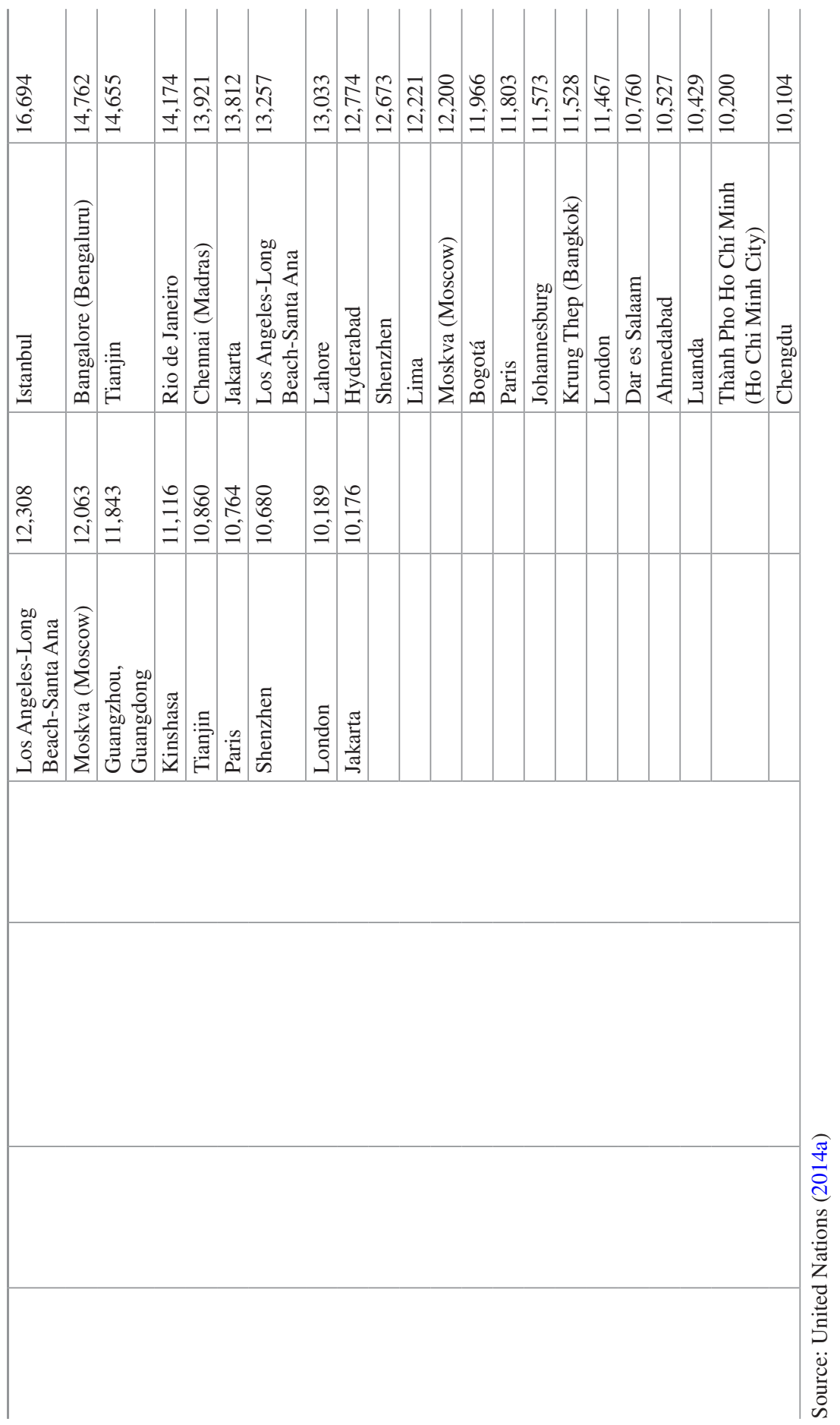




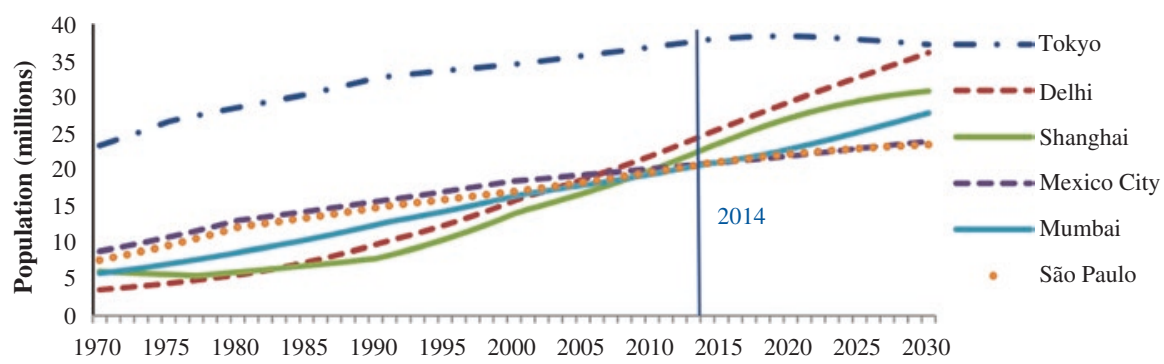

Fig. 2.8 Population of the largest cities in 2014, from 1970 to 2030. (Source: United Nations 2014c, 1)

such agglomeration was located in Asia in 1950, but by 2001, 10 of the 18 global megacities were in Asia. In 2014, there were 28 world megacities, of which 16 were in Asia. In 2014, some $12 \%$ of the world's urban dwellers lived in megacities (United Nations 2014c).

Projections of world megacities in 2030 predict that the seven largest megacities will be in Asia, from Tokyo (37.2 million) to Karachi (24.8 million). Of the 42 countries with more than 10 million inhabitants, 23 will be Asian.

Figure 2.8 shows the past and anticipated future growth of the world's largest six cities, of which four are Asian. Although Tokyo's population is expected to decline, it is expected to remain the largest city with 37 million inhabitants in 2030. However, by then, the same population level will be almost reached by Delhi, for which the projected population is 36 million.

However, the poor measurement of Asian city size means that these figures substantially underestimate both the total number of Asian megacities and their size. Jones and Douglass (2008) have demonstrated this by considering the several ASEAN coastal capitals that have indeed passed the ten-million resident threshold (Jakarta, Bangkok, Ho Chi Minh City). This undoubtedly is the case also for Chinese cities like Shenzhen, Chongqing and Guangzhou. These megacities are playing a major role in the development of the PRC and ASEAN countries, and it is crucial that we develop better ways of delineating their boundaries so they represent the functional mega-urban areas. The remarkable growth of Chinese cities especially has not been well captured in these data. One striking example is the city of Shenzhen, one of the first special economic zones in the PRC. From a population of 20,000 in 1980, Shenzhen had reached 12 million and megacity status within just 40 years (Shen 2008).

The spatial distribution of cities with more than two million inhabitants in Asia indicates the strong coastal orientation in the location of large cities, especially megacities. This is partly a function of the strong colonial heritage of these large coastal port cities (McGee 1967). The lack of large cities in the inland is strongly in evidence. The East-West divide in the PRC also strikingly reflects the strong spatial divide in development between the two parts of the nation. It contrasts with India where the distribution of large cities is more evenly spread geographically. The lack 
of urban development in the poorest and least developed parts of the region such as Eastern Indonesia, Lao People's Democratic Republic and Cambodia is clear.

The strong coastal orientation of Asia's megacities and indeed of the total urban population has some implications from the perspective of climate and environmental change, particularly in terms of a substantial exposure to the risk of impact from sea level rise. Accordingly, in a global assessment (Wheeler 2011) of the projected population at risk from sea level rise in 2050, the 20 countries with the largest numbers included 11 Asian countries of which 6 were Southeast Asian-Indonesia (20.9 million people), the Philippines (13.6 million), Viet Nam (9.5 million), Myanmar (4.6 million), Malaysia (3.5 million) and Thailand (2.6 million). McGranahan et al. (2007) identified the global population living in urban areas in the low elevation coastal zone (LECZ, coastal areas $10 \mathrm{~m}$ or less below sea level). Of the ten nations with the largest numbers of people living in the LECZ, eight are Asian and four are in Southeast Asia_-Viet Nam, Indonesia, Thailand and the Philippines.

Internal migration in Asia is increasingly characterized by:

- Increasing settlement in coastal areas.

- Increasing urbanization.

In fact, current patterns of internal migration in many countries are increasingly concentrating national population in areas with high risk of being influenced by climate change. The Asian megacities vary in their exposure to the risk of sea level rise, as Table 2.8 shows (Hugo and Bardsley 2014).

In recent discussions of urbanization, there has been a focus on megacities, yet it is apparent that small- and medium-sized cities are also making a major contribution to urban growth, especially in large nations like the PRC, India and Indonesia. Smaller- and medium-sized cities also are experiencing 'extended urbanization' in that they are expanding beyond their boundaries and creating what Zhu (2004) describes in the PRC as 'in situ urbanization', whereby hitherto rural populations are 'swallowed up' by expanding urban areas. A study by Fahmi et al. (2014) examines Cirebon in Indonesia where the city has 300,000 inhabitants and an additional 400,000 live in the outer areas surrounding the city proper. There are real problems in providing services and infrastructure to such areas.

Table 2.8 Southeast Asia: megacities' projected population 2005-2025

\begin{tabular}{l|l|l|r|r}
\hline & & \multicolumn{3}{l}{ Population ('000) } \\
\cline { 3 - 5 } & Average height above sea level & 2005 & 2020 & 2025 \\
\hline Bangkok & $2 \mathrm{~m}$ & 6,582 & 7,807 & 8,322 \\
\hline Jakarta & $8 \mathrm{~m}$ & 8,643 & 11,682 & 12,363 \\
\hline Manila & $16 \mathrm{~m}$ & 10,761 & 13,892 & 14,808 \\
\hline Ho Chi Minh City & $19 \mathrm{~m}$ & 5,072 & 7,293 & 8,149 \\
\hline
\end{tabular}

Source: United Nations (2008) 


\section{Drivers of Urbanization and Urban Growth}

The dynamics of rapid urbanization and urban growth in Asia are complex. However, much of the discourses see urbanization purely as a permanent shift of people involving migration from living in a rural location to living in an urban one. However, there are a number of processes involved:

- Natural increase (i.e. excess of births over deaths)

- Net internal migration (i.e. excess of immigrants from elsewhere in the country compared with out-migrants moving to such areas)

- Net international migration (an excess of immigrants from other countries over emigrants moving to such countries)

- Reclassification of areas from being classified as rural to urban, often by the lateral extension of large urban areas to swallow up surrounding rural areas and smaller cities and towns

Unfortunately, the relative contribution of these four factors of urban growth in Asia over the last 15 years has not been calculated. In fact, this estimation has only been made for the 1960s, 1970s and 1980s (United Nations 2001). One more recent estimate suggests that $40 \%$ of the increase in the urban population in developing countries comes from migration or reclassification of the rural to the urban. In the large countries of the PRC and Indonesia, however, these two factors accounted for more than $70 \%$ of urban growth (World Bank and IMF 2013, 85).

While the emphasis is on internal rural-urban migration as the major driver of rapid growth in urban areas, in most countries, it accounts for less than half of net urban growth. Nevertheless, rural to urban migration is not only important in influencing a nation's demography but also often associated with substantial social and economic transformations.

As the urban populations of Asian countries increase rapidly, it is the children born to the urban residents that are becoming a major factor in the growth of these centres. However, an important characteristic of all Asian countries is that, as Table 2.9 shows, fertility levels are generally significantly lower in urban areas than in rural. This consistent feature of Asian demography has been seen in the past as being largely a function of the educational, income and occupational differentials between urban and rural areas. However, work in Africa (Brockerhoff 1998) has shown that, even when holding such differences constant, urban fertility is lower, thus indicating that there may be something about urban living and conditions that works independently to lower fertility. This may be such things as greater housing pressures, the type of work of women which makes it more difficult to keep working while having young children than in the village, difficult patterns of marriage and partnering, different peer group pressures and influences, etc.

Nowhere in Asia have urban-rural differentials in fertility decline been greater than in the PRC (Lavely and Freedman 1990; Yao 1995; Zhao 2001). Figure 2.9 shows that in the PRC's dramatic fertility decline, the fall has been more dramatic in urban than rural areas. The urban total fertility rate (TFR) had fallen to 1.13 in the 
Table 2.9 Selected Asian countries: differences in total fertility rate between urban and rural areas

\begin{tabular}{l|l|l|l|l}
\hline Country & Year & $\begin{array}{l}\text { Urban fertility } \\
\text { rate }\end{array}$ & $\begin{array}{l}\text { Rural fertility } \\
\text { rate }\end{array}$ & $\begin{array}{l}\text { Percent lower in } \\
\text { urban areas }\end{array}$ \\
\hline Bangladesh & 2011 & 2.0 & 2.5 & 20.0 \\
\hline Cambodia & 2010 & 2.2 & 3.3 & 33.3 \\
\hline India & $2005-2006$ & 2.1 & 3.0 & 30.0 \\
\hline Indonesia & 2012 & 2.4 & 2.8 & 14.3 \\
\hline Maldives & 2009 & 2.1 & 2.8 & 25.0 \\
\hline Nepal & 2011 & 1.6 & 2.8 & 42.9 \\
\hline Pakistan & $2012-2013$ & 3.2 & 4.2 & 23.8 \\
\hline Philippines & 2013 & 2.6 & 3.5 & 25.7 \\
\hline Sri Lanka & 1987 & 2.1 & 2.8 & 25.0 \\
\hline Thailand & 1987 & 1.7 & 2.4 & 29.2 \\
\hline Timor-Leste & $2009-2010$ & 4.9 & 6.0 & 18.3 \\
\hline Viet Nam & 2002 & 1.5 & 2.0 & 25.0 \\
\hline
\end{tabular}

Source: Demographic and Health Surveys, STATcompiler

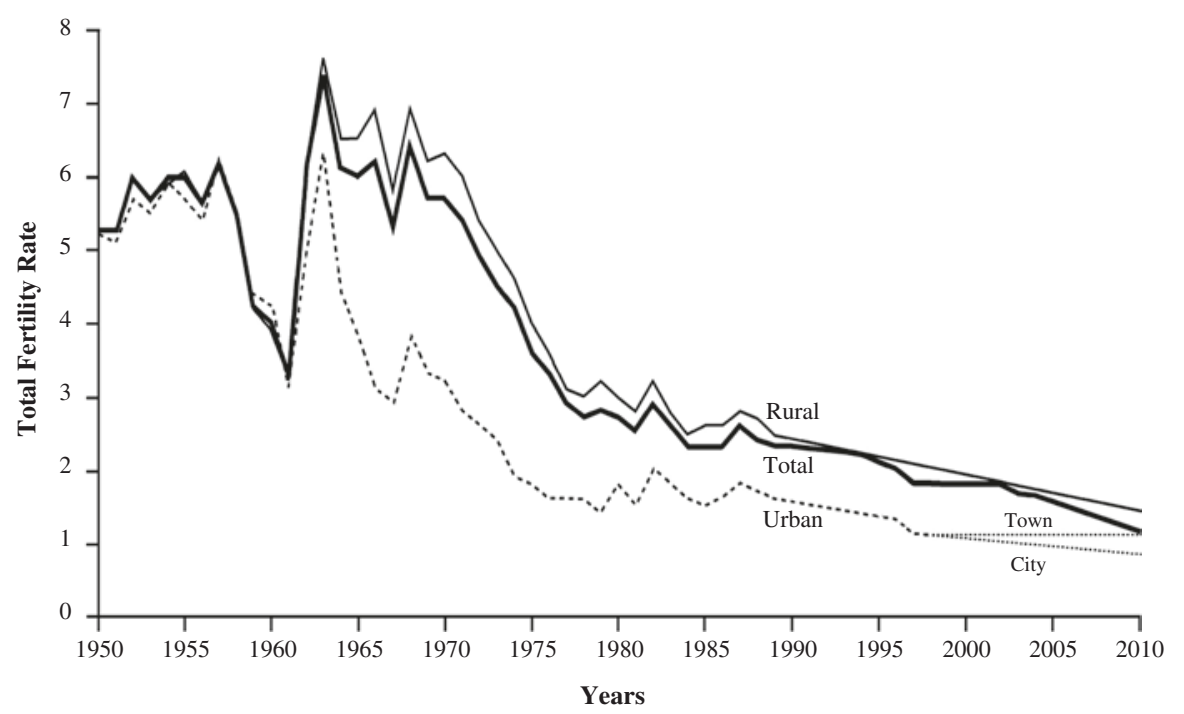

Fig. 2.9 People's Republic of China: total fertility rate, 1950-2010. (Source: Zhao 2001; Peng 2004, 136; 2010 Census of PRC)

late 1990s, while that in Shanghai was 0.87 (Yuan 2003)—one of the lowest rates of any place in the world.

The lower fertility in urban than rural areas means that despite most urban areas having lower mortality than rural areas, natural increase rates are lower in urban than rural areas. However, the build-up of massive urban populations means that in many countries the numerical size of the natural increase is very large.

Another aspect of the decreased fertility in Asian urban areas, especially where it has fallen well below replacement levels, as in the PRC, is the impact on age 
Table 2.10 Change of age structure in Shanghai (percent)

\begin{tabular}{l|l|l|l}
\hline Year & $0-14$ & $15-64$ & $65+$ \\
\hline 1964 & 42.31 & 54.08 & 3.61 \\
\hline 1982 & 18.15 & 74.25 & 7.60 \\
\hline 1990 & 18.23 & 72.39 & 9.38 \\
\hline 2000 & 12.26 & 76.28 & 11.46 \\
\hline 2010 & 8.61 & 81.26 & 10.13 \\
\hline
\end{tabular}

Source: Child Population Censuses in 1964, 1982, 1990, 2000 and 2010

structure and thus on the size and characteristics of its working population, the demand for health services, social security for the elderly and so on. We will examine here the Chinese city of Shanghai, the changing age structure of which is shown in Table 2.10. This demonstrates the massive changes over the recent decades. First, the impact of the plummeting fertility that saw the proportion made up of the dependent child age groups (0-14 years), which made up $42.3 \%$ of the total city population in 1964. This declined rapidly in the 1980s, and by 2010 , only $8.6 \%$ of Shanghai's population was in this age group. On the other hand, the percentage aged $65+$ increased from $3.6 \%$ in 1964 and increased to $11.5 \%$ in 2000. Particularly striking, however, was the proportion of the working population in the total population increasing from $54.1 \%$ to $81.3 \%$ between 1964 and 2010. In fact, this change in age structure in Shanghai (and in the PRC) has delivered a marked demographic dividend. An important issue here is that the pattern of age structure in Shanghai is duplicated across other Asian cities, albeit often in a less spectacular way. It is important to note that one of the elements which contribute to Asia's urban areas being an 'engine of growth' in the region is the demographic dividend factor.

The demographic dividend can be defined as follows:

A rapid decline in fertility such as China has experienced can create a 'youth bulge' of large numbers of young people born in the final years of high fertility. As they move through the age pyramid they can deliver a demographic dividend of economic growth when the bulge passes through the working age groups so that the workforce grows faster than the total population. If countries take advantage there is a virtuous cycle of wealth creation. (Bloom et al. 2003, 39).

This virtuous cycle is created through:

- Increased labour supply, with women more ready to enter the workforce.

- Increased savings.

- Increased human capital investments.

However, there is a need for a favourable policy environment to be put in place if this dividend is to be realized.

Although Asia's cities will continue to grow, the effects of continued low fertility will be very much felt in the cities. It already has been shown that these nations will record significant ageing of their populations and resultant imbalances between working age and aged dependent populations. These effects will be greater in cities than elsewhere in these nations since, in many cases, the percentage of the aged 
population living in urban areas will be greater than the percentage of the total population living in cities. This is due to the fact that there tends to be net migration gains of the 'old-old' population due to the greater availability of high-order health facilities and specialized housing and other care services for the aged in larger cities. In addition, aged people often migrate to join their children who have moved to cities. Hence an important point here is that while overall urban populations in Asia will continue to increase, the balance between their working age and older populations will deteriorate, and the workforce itself will age as the effects of fertility decline exacerbate.

The low-fertility and ageing populations of urban areas of Asia would indicate that other things being equal, they will grow more slowly than national populations. Net migration gain is essential to the demographic, economic and social sustainability of Asian cities. There will be a need for 'replacement migration' to occur. This concept was developed in relation to the needs of low-fertility European countries that currently or in the near future will experience population declines due to continued low fertility and the potential of countries of the south to make up the shortfalls through international migration. It came to particular prominence in early 2000 when the United Nations Population Division (2000: 01) published a report entitled 'Replacement Migration: Is It a Solution to Declining Aging Populations? The report defined 'replacement migration' as 'the international migration that would be needed to offset declines in the size of population, the declines in the population of working age, as well as to offset the overall ageing of the population'. While the report attracted a great deal of comment and criticism when it was published, the 'replacement migration' concept was a useful one because it pointed to the fact that migration was going to play a more significant role in the European countries than it had in the past.

In the current context of cities in Asia, it needs to be stressed that internal migration of young people to the cities is replacing the local young workers that would have been moving into the workforce age had it not been for the extremely low fertility.

\subsection{Internal Migration and Urban Development in Asia}

Population movement has played a key role not only in the growth of urban centres in Asia but also strongly influenced the social, economic and demographic structure and development of these centres. From the perspective of the growth of urban centres, it is apparent that net internal migration from the rural areas has been substantial. While intercensal reclassification of rural areas as urban due to the lateral expansion of urban areas has been important, rural-urban immigration has been a major engine of growth. Table 2.11 shows estimates of the components of growth in several major Asian cities in the 1990-2000 period. It indicates that net migration has been substantial. In 2005, Shanghai had a population of 17.78 million of which 4.38 million were migrants who had lived in the city for more than 6 months. 
Table 2.11 Contribution of net migration to population change in Asian megacities, 1990-2000 (percent)

\begin{tabular}{|c|c|c|c|c|c|c|}
\hline Subregion of megacity & Jakarta & Bangkok & Manila & $\begin{array}{l}\text { Ho Chi } \\
\text { Minh } \\
\text { City }\end{array}$ & Shanghai & Taipei,China \\
\hline Core & Negative & 3 & 19 & na & 11.4 & Negative \\
\hline Inner zone & 60.9 & 71 & 54 & na & 94.7 & 31.9 \\
\hline Outer zone & Negative & 62 & 42 & na & 62.4 & 40.7 \\
\hline Mega urban region & 16.2 & 52 & 38 & 46.3 & 104.4 & na \\
\hline
\end{tabular}

Source: Jones and Douglass 2008

Note: $n a$ not available

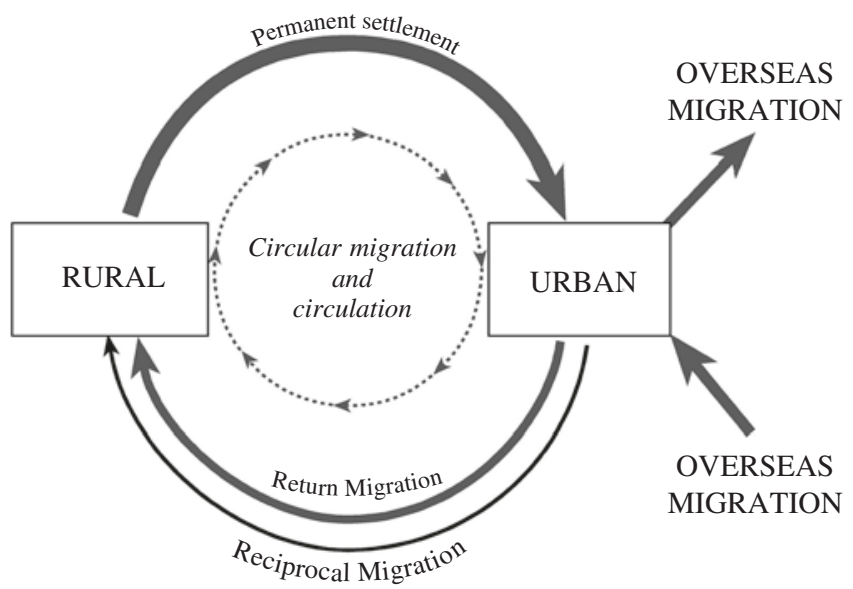

Fig. 2.10 A model of rural-urban population mobility in Asia

Moreover, one-third of all babies delivered were born to migrants (Xinhua News Agency, 7 April 2006). This shows the major role that migration is already playing in Shanghai's demography. The table shows that were it not for the net migration factor, Shanghai's population would have declined over the 1990-2000 period.

Table 2.11 shows that the contribution of net migration to the growth of four ASEAN megacities varied between $16.2 \%$ in Jakarta and 52\% in Bangkok.

The increasing complexity of rural-urban migration and urbanization in Asia is depicted in Fig. 2.10, which is a model of the main forms of rural-urban migration. It indicates that permanent displacement from rural to urban areas is only one of the elements involved. There is a great deal of circular migration in Asian countries like the PRC (Zhu 2007) and Indonesia (Hugo 1982). This often involves a migrant leaving his/her family in the village and then returning to the village periodically while working in the city.

One of the distinguishing features of the PRC's urban population is the duality between the resident population and the migrant worker population that largely comprises circular migrants. Such a distinction applies in all other Asian urban areas between a permanently settled resident population and a temporarily present group of 'circular migrants' from the outside. 
Many commentators in the PRC have emphasized the need for the migrant worker population to become permanent urban residents and for this duality in Chinese cities to be ended, with migrant workers becoming integrated as settled city residents. While these recommendations have considerable merit, research findings on circular migration not only in the PRC (Zhu 1999; Hugo et al. 2009) but also elsewhere (Hugo 1982, 2009) have indicated that a more nuanced policy towards circular migration would have greater dividends for economic development and poverty reduction in Asian urban areas.

One of the 'truisms' of migration research is that 'there is nothing so permanent as a temporary migrant' (Martin 2001: 01). This is based on the belief that all temporary migrants see their current non-permanent status as a preliminary stage before they are able to settle permanently at the destination. If given the opportunity, they will make the transition from temporary to permanent residence. However, research in both internal (Hugo 1978, 1982) and international migration (Hugo 2009) has shown that while some temporary migrants certainly fit this description, for others, circular, temporary migration is seen as a persistent, continuing and preferred mobility strategy. For some temporary migrant workers in Chinese cities, there are significant advantages to circular migration between rural and urban areas over permanently settling in the city. Box 2.1 summarizes some of the main advantages that accrue from circular migration as a rural-urban mobility strategy. These advantages apply at individual, family, community and sectoral levels. Of course, there are disadvantages that are associated with circular migration as well, which are summarized in Box 2.2.

\section{Box 2.1 Advantages of Circular Migration to Asian Cities}

Source: IOM (2015)

- Circular migration allows poorer families to maximize income and spread risk of income failure by facilitating working in both rural and urban areas and in both agricultural and non-agricultural sectors.

- It maximizes the benefit of this income by earning in the city, where both wages and costs are higher, and spending in the village, where both are lower.

- It facilitates the redistribution of wealth from the fast-developing urban areas, which are the centre of investment and economic growth, to peripheral and poorer rural areas, which lack such investment.

- It provides a scarce source of funds in rural areas to facilitate job creation and development in those areas.

- It reduces the pressure on urban areas to provide housing, schooling, infrastructure, health facilities, etc., for their inhabitants.

- In the PRC, if a circular migrant keeps his rural hukou, he can have two or three children rather than one, which is enforced in the city.

- In the PRC, if a migrant surrenders his rural hukou, he will have to give up his land. Land is an important consideration for support in old age.

- In the PRC, some migrant workers are also reluctant to pay the high costs of being an urban resident through taxes, contributions to health and pension schemes, etc. 


\section{Box 2.2 Disadvantages of Circular Migration}

Source: IOM (2015)

- The social costs of separation from family can be substantial and very painful to the people involved, especially where there is a great distance separating the origin and the destination. In the PRC, only $20 \%$ of migrant workers bring their families with them (Jun 2010, 4).

- It is difficult to adjust to the time demands of modern-sector jobs, which require 5-6 day weeks and $8 \mathrm{~h}$ days of their workers.

- The origin community can lose substantial numbers of its youngest, entrepreneurial and most economically and socially active members for long periods as a result of which economic and social capital is diminished in those areas.

- Migrant workers in the destination can experience considerable hardship because of their marginal position and their lack of access to urban services.

The important point to make here is that not all migrant workers in Asian cities want to shift permanently to live in large cities. Moreover, it needs to be recognized that both permanent rural to urban relocation and circular migration between rural and urban areas can have positive outcomes on development and poverty reduction:

- For those who permanently relocate, their personal situation improves because they gain access to all the services available in the city; they get the chance to increase their incomes and gain access to education, health and other services for their families.

- However, circular migration has also been shown to have the potential to deliver development dividends (Hugo 2009) and reduce poverty in rural communities. Migrant workers remit much of their earnings back to rural communities, which can be used not only to improve the situation of their village-based families but also the local community through their investment in it. Moreover, returning workers bring back new ideas and ways of doing things and can potentially invest in productive activity in their home communities. Circular migration provides the potential for the benefits of rapid economic growth in cities to be spread to the countryside.

Hence, there is great complexity in the substantial contribution that internal migration is making to the growth of urban areas in Asia. Yet there is another type of migration which is also increasingly shaping the size, composition and function of urban population in Asia-international migration. 


\section{International Migration and Urban Development in Asia}

A final dimension of population mobility that needs to be mentioned when considering urbanization in Asia is international migration. Of course, international migration has not been as substantial an element in Asian urbanization as it has in contemporary population growth in the major cities of Euro-American societies. Nevertheless, international migration is assuming greater significance, especially in cities in the most developed economies in the region. In Singapore, for example, it is now estimated that $36 \%$ of the population comprises foreign citizens and $27.7 \%$ of the workforce comprises foreigners (Hugo 2004). In Hong Kong, China, 6.7\% of the population are citizens of other economies (Chiu 2003). The number of foreign nationals in 2010 in Japan was over 2.2 million, and there were some 224,067 overstaying illegal migrants, most of them in the nation's urban areas (Hayashi 2013). In Seoul, the number of foreign residents increased from 114,685 in 2004 to 129,660 in 2005 (Asian Migration News, 15-31 June 2006). In cities like Kuala Lumpur and Bangkok, there are also significant numbers of foreigners, although in the PRC and India's cities, the number of foreigners in cities is still quite small, but it is certainly growing as these cities are becoming more globally linked. As the megacities of the Asian region become 'world cities', their economic and social linkages to other countries grow (Sassen 1991; Friedmann 1986). Along with this, multinational corporations are increasingly locating activities in these cities and transferring their multinational workers in and out. Moreover, with increasing economic and political cooperation between nations in the region such as ASEAN and Asia-Pacific Economic Cooperation (APEC), the barriers to some movements have been reduced a little. This is especially true of student and skilled migrations. Moreover, there are forces in the cities of the better-off nations of the region that are creating a demand for unskilled workers, especially in niches that have low status, insecurity and low wages. Accordingly, unskilled immigrants are becoming increasingly evident in many Asian cities. It is important to stress that most of the increasing international migration to Asian countries is destined for urban locations so its impact is highly concentrated in cities, especially the largest cities.

There are a number of elements in the increasing international migration being directed into Asia's largest cities. Most of the migrants are from other, usually nearby, Asian countries, and much of the movement is from less developed, labour surplus continents to more developed, better-off labour deficit economies. However, there is also a movement of more skilled persons (Hugo 2014), often employed by multinational companies, from OECD and more developed Asian countries to less developed nations. This is partly a function of the human resource policies of multinational companies but also reflects the fact that the education/training systems in some economies are a mismatch with the skills needed in rapidly developing economies, which is why they need to bring in management, engineering and other skills.

In summary, the main international migrations into Asian cities are as follows:

- There is an inflow of a professional and managerial group of expatriates. This group is increasing in size throughout the region, and while it involves some 
foreigners of Asian origin, especially from India and the Philippines, skilled people from Europe, North America, Japan, the Republic of Korea and AustraliaNew Zealand predominate. It is partly associated with increased foreign direct investment in these cities and the associated transfer of staff from parent companies located in MDCs. It also includes other skilled people who are in demand because local mismatches between rapidly growing and restructuring economies demand jobs which cannot be met by the local training/education system.

- International students are increasingly mobile within the Asia region. Asia has been for some time the major origin of students to OECD countries (Abella 2005; Kritz 2006), but there is an increasing movement to other Asian countries. For example, $20 \%$ of Singapore's university students are foreign. There have also been large student migrations to Malaysia, the PRC, Japan and the Republic of Korea.

- There is a substantial influx of women to work as domestic maids, especially in the cities in the newly developing economies (NDEs)_-Taipei,China; Hong Kong, China; Singapore; Brunei Darussalam; and Malaysia. They are predominantly drawn from Indonesia, the Philippines and Sri Lanka and number more than two million (Huang et al. 2005).

- The construction industry in many cities in NDEs is dominated by foreign workers. In several economies, low-skilled foreign workers have been brought in to work in factories and in other low-pay, low-skill areas.

- The so-called entertainment or sex industry is an important element in the major cities (Lim 1998), and in several places, foreigners, especially women, are involved. Undocumented workers often trafficked into the country are substantial.

- In several cities, foreign workers, many of them undocumented, have become an important part of the informal sector.

- The gender differentials discussed earlier are contributing to increased marriage migration of women in the Asian region. Hugo (2006) shows that a third of marriages in the Republic of Korea and a quarter in Taipei,China, are now to foreigners, mostly from elsewhere in Asia. Asian international marriage is also being driven by increased global movement of young Asians, the role of a burgeoning marriage migration industry and the changing role of women in many receiving economies.

All of these increasing flows of intra-Asian international migration are disproportionately concentrating foreign populations in the cities of Asia. They are leading to increased diversity in these cities_-even in places like Japan, the Republic of Korea and Taipei,China, which have traditionally stressed their ethnic homogeneity. Other cities like Singapore, Kuala Lumpur, Jakarta, Bangkok and Ho Chi Minh have long had ethnic diversity because of the diversity of the nations in which they are located and earlier waves of international migration from the PRC and India. As the demographic and development differences between Asian economies become more stark, it is likely that the pressures for international migration to fast-growing cities in better-off economies will continue. 


\section{Conclusion}

Urban areas house more than a half of Asia's population, while two generations previously, only one in ten Asians lived in urban areas. This represents a profound change in the way in which Asians live their lives. However, there are many challenges that Asian urbanization presents to policymakers, planners and researchers. One crucial area lies in the arena of data collection and research. Planning for efficiency and equity in Asian cities requires timely and relevant research. However, in Asia, as elsewhere, conceptualization and definition of urban areas has remained mired in the thinking of the 1970s and does not capture the nature of contemporary dynamic urban systems. Moreover, data collection systems are based on large areas, while modern technology allows small building block units for censuses and other data collection, which in turn allows flexible and appropriate definition of urban boundaries. Sound planning and governance of urban centres in Asia require better delineation of boundaries and of appropriate specifically disaggregated data within those boundaries. Moreover, research in urban areas needs to be integrated so that an understanding of the dynamics of population change in urban areas may be achieved.

While there is variation between Asian cities in the extent of fertility decline and ageing, there can be no doubt that in several major cities in the region, especially those in the PRC, considerable challenges will be experienced especially in terms of:

- A reduction in the number of local young people entering the workforce.

- A rapid growth in the elderly population and in their ratio to the replacement working age population.

Migration from internal, and to a lesser extent international, sources will be essential to the sustainability of those cities that are most strongly affected. There is no doubt that the proportion of immigrants of major cities in several Asian nations is likely to continue to increase. This, however, is not simply a function of 'replacement migration'. There are a number of processes operating to increase migration, both internal and international, in Asia. Moreover, that migration is disproportionately directed towards major cities, and this will continue because the labour markets into which they predominantly move are found in those centres. The forces of globalization and economic restructuring which are reshaping the economic and social, as well as physical, form of Asia's major cities of north nations have included an important population movement component. Indeed, an increased volume of international migration has been identified as one of the key defining characteristics of world cities (Friedmann 1986) and global cities (Sassen 1991).

Asian cities have undergone substantial demographic change in the last decade, and these trends seem likely to continue over the next two decades. These changes are both interrelated with social, economic and political transformations occurring 
in those cities and have implications for those transformations. The shifts can be summarized as follows:

- The overall growth of urban populations will be slower than in the past half century but will continue at a significantly higher rate than in national populations.

- The working age population will stabilize because of low fertility, meaning the numbers of local people moving into the working age will decrease.

- The aged population will increase substantially, creating increased pressure on pension schemes, health services and so on.

- The distinctive residential pattern of aged populations will be increasingly evident in north cities, and the services they require will account for an increased part of the workforce.

- Ageing of the population will result in different demands for transport, housing, retail services, human services and so forth.

- There will be increased levels of female participation in the urban workforce and an increase in the average age of retirement.

The future of these cities will depend to a large degree on the extent to which immigration can compensate for the slow local growth (or decline) of the workforce and ageing. Much will therefore depend on the policies at the city, regional and national levels towards migration, both internal and international. Currently, throughout much of Asia, there are policies in place that are effectively antimigration and anti-migrant. Migration is too often seen as a temporary necessity rather than a crucial long-term structural feature of these cities. Emphasis is on stopping migration altogether or restricting it in a variety of ways. Yet migration is crucial to both the short-term and especially the longer-term sustainability of those cities. There is a need for policies that accept this reality and hence facilitate the flow of migrants and protect their rights as being important contributors to the prosperity of cities. Hence, policies towards not only who may enter a country or city but also newcomers settling in cities on a permanent or temporary basis need to be reconsidered. Too often, migrants are unfairly negatively stereotyped or made scapegoats for cities' problems like crime, health, pressure on services and environmental degradation. They need to be seen as being significant, indeed in being increasingly significant, to the long-term sustainability of cities. However, development of appropriate policies with respect to migrants and migration needs to be based upon an understanding of the relevant migration processes. This understanding can be an important separate tool that urban policymakers and planners can use to not only accommodate rapid demographic change but also meet it head on and initiate interventions to maximize its potential benefits and minimize its negative impacts. 


\section{References}

Abella, M. I. (2005 January 13-14). Global competition for skilled workers and their consequences. Paper presented at Conference on Competing for Global Talent, Singapore Management University, Singapore.

Bloom, D. E., Canning, D., \& Sevilla, J. (2003). The demographic dividend: A new perspective on the economic consequences of population change, Population matters. Santa Monica: RAND.

Brockerhoff, M. (1998). Migration and the fertility transition in African cities. In R. E. Bilsborrow (Ed.), Migration, urbanization, and development: New directions and issues (pp. 357-390). New York: UNFPA.

Champion, A., \& Hugo, G. (Eds.). (2004). New forms of urbanisation: Beyond the urban-rural dichotomy. Aldershot: Ashgate.

Chiu, S. W. K. (2003, February 6-7). Recent trends in migration movements and policies in Asia: Hong Kong region report. Paper prepared for Workshop on International Migration and Labour Markets in Asia, Japan Institute of Labour, Tokyo.

Deichmann, U., Shilpi, F., \& Vakis, R. (2009). Urban proximity, agricultural potential and rural non-farm employment: Evidence from Bangladesh. World Development, 37(3), 645-660.

Fahmi, F. Z., Hudalah, D., Rahayu, P., \& Woltjer, J. (2014). Extended urbanization in small and medium-sized cities: The case of Cirebon, Indonesia. Habitat International, 42, 1-10.

Friedmann, J. (1986). The World City Hypothesis. Development and Change, 17, 69-83.

Hayashi, R. (2013, October 31). Introduction. Presentation to the 18th Institute of Population and Social Security (IPSS) Annual Seminar, 'New Trends in International Migration-Towards a Japanese Model', National Institute of Population and Social Security Research, Tokyo, Japan.

Huang, S., Yeoh, B. S. A., \& Rahman, N. A. (Eds.). (2005). Asian women as transnational domestic workers. Singapore: Marshall Cavendish.

Hugo, G. J. (1978). Population mobility in West Java. Yogyakarta: Gadjah Mada University Press.

Hugo, G. J. (1982). Circular migration in Indonesia. Population and Development Review, 8(1), $59-84$.

Hugo, G. J. (2004, April 28-30). Labour mobility and urbanisation in Asia: Lessons learned and good practices. Paper prepared for China Employment Forum organised by the Ministry of Labour and Social Security of China and the International Labour Office, Beijing.

Hugo, G. J. (2006, August 10-11). Cross national marriage in Asia: Trends and issues. Presentation to workshop on cross national marriage in globalized background, University of Social Sciences and Humanities National University of Ho Chi Minh City, Ho Chi Minh City, Vietnam.

Hugo, G. J. (2009). Circular migration and development: An Asia-Pacific perspective. In O. Hofirek, R. Klvanova, \& M. Nekorjak (Eds.), Boundaries in motion: Rethinking contemporary migration events (pp. 165-190). Brno: Centre for the Study of Democracy and Culture.

Hugo, G.J. (2014, September 22-23). High skilled migration to Asian Nations. Paper prepared for US National Academies' Board on Science, Technology and Economic Policy Conference on Global High Skilled Immigration Policy, Keck Center, Washington, DC.

Hugo, G. J., \& Bardsley, D. (2014). Migration and environmental change in Asia, chapter 2. In E. Piguet \& F. Laczko (Eds.), People on the move in a changing climate: Comparing the impact of environmental change on migration in different regions of the world (pp. 21-48). Dordrecht: Springer.

Hugo, G.J., Bardsley, D.K., Tan, Y., Sharma, V., Williams, M. \& Bedford, R. (2009, August). Climate change and migration in the Asia-Pacific region (Final Report to Asian Development Bank).

International Organization for Migration. (2015). Urban migration trends, challenges, responses and policy in the Asia-Pacific. IOM world migration report 2015.

Jones, G. W. (2002). Southeast Asian urbanization and the growth of mega-urban regions. Journal of Population Research, 19(2), 119-136.

Jones, G. W. (2004). Urbanization trends in Asia: The conceptual and definitional challenges. In A. Champion \& G. Hugo (Eds.), New forms of urbanization (pp. 113-132). Aldershot: Ashgate. 
Jones, G. W., \& Douglass, M. (Eds.). (2008). Mega-urban regions in Pacific Asia: Urban dynamics in a global era. Singapore: National University of Singapore Press.

Jun, H. (2010). Study on social service delivery in rapid urbanization of the People's Republic of China. Study for Asian Development Bank.

Kritz, M. M. (2006, June 28-30). Globalisation and Internationalization of Tertiary Education. Paper prepared for the symposium on international migration and development, Turin, Italy.

Lanjouw, P., \& Marra, M. (2012). Urban poverty and city size in Viet Nam. Washington, DC: World Bank.

Lavely, W., \& Freedman, R. (1990). The origin of the Chinese fertility decline. Demography, 27, 357-367.

Lim, L. L. (Ed.). (1998). The sex sector: The economic and social bases of prostitution in Southeast Asia. Geneva: International Labour Office.

Martin, P. (2001, April). There is nothing more permanent than temporary foreign workers, Backgrounder, Center for Immigration Studies.

McGee, T. L. (1967). The Southeast Asian city: A social geography of the primate cities. London: G. Bell.

McGranahan, G., Balk, D., \& Anderson, B. (2007). The rising tide: Assessing the risks of climate change and human settlements in low elevation coastal zones. Environment and Urbanization, $19,17-39$.

Peng, Z. (2004, March). Is it time to change China's population policy? China: An International Journal, 2(1), 135-149.

Sassen, S. (1991). The global city: New York, London, Tokyo. Princeton: Princeton University Press.

Shen, J. (2008). Urban growth and sustainable development in Shenzhen City 1980-2006. The Open Environmental Journal, 2, 71-79.

Tie, L. (2010). Urban development strategy in the People's Republic of China. Study for Asian Development Bank.

United Nations. (2000). Replacement migration: Is it a solution to declining and ageing populations? New York: United Nations.

United Nations. (2001). The components of urban growth in developing countries. September, ESA/P/WP.169, Population Division, Department of Economic and Social Affairs, United Nations, New York.

United Nations. (2008). World urbanization prospects: The 2007 revision. New York: United Nations.

United Nations. (2014a). World urbanization prospects: The 2014 revision, data in Excel files. http://esa.un.org/unpd/wup/CD-ROM/Default.aspx. Accessed 1 Dec 2014.

United Nations. (2014b). Population facts-Our urbanizing world. August, No. 2014/3, Department of Economic and Social Affairs, Population Division, United Nations, New York.

United Nations. (2014c). Population facts - A world of cities. August, No. 2014/2, Department of Economic and Social Affairs, Population Division, United Nations, New York.

Wheeler, D. (2011, January). Quantifying vulnerability to climate change: Implications for adaptation assistance (Working Paper 240). Washington, DC: Center for Global Development.

World Bank. (2011). Vietnam urbanization review (Technical assistance report). Washington, DC: World Bank.

World Bank. (2014). World development indicators online. http://data.worldbank.org/indicator/ NY.GDP.PCAP.CD. Accessed 9 Dec 2014.

World Bank and International Monetary Fund. (2013). Global monitoring report 2013: Ruralurban dynamics and the millennium development goals. Washington, DC: World Bank.

Yao, X. (1995). Fertility data of China [in Chinese], Beijing: China Population Publishing House.

Yuan, X. (2003, December 10-12). Impacts of rapid fertility decline and rural-urban temporary migration on age structure of large cities in China, presented at the Workshop on Population Changes in China in the Beginning of the 21st Century, Canberra, Australia. 
Zhao, Z. (2001, April). Low fertility in urban China, presented at IUSSP Low Fertility Working Group Seminar on International Perspective on Low Fertility: Trends, Theories and Policies, Tokyo.

Zhu, Y. (1999). Seeking more balanced patterns of urbanisation: Case studies in Fujian Province of China. Unpublished PhD thesis. Demography Program, Research School of Social Sciences, Australian National University, Canberra.

Zhu, Y. (2004). Changing urbanization processes and in situ rural-urban transformation: Reflections on China's settlement definitions. In A. Champion \& G. Hugo (Eds.), New forms of urbanization (pp. 207-230). Aldershot: Ashgate.

Zhu, Y. (2007). China's floating population and their settlement intention in the cities: Beyond the Hukou reform. Habitat International, 31(1), 65-76.

The views expressed in this publication are those of the authors and do not necessarily reflect the views and policies of the Asian Development Bank (ADB) or its Board of Governors or the governments they represent.

ADB does not guarantee the accuracy of the data included in this publication and accepts no responsibility for any consequence of their use. The mention of specific companies or products of manufacturers does not imply that they are endorsed or recommended by ADB in preference to others of a similar nature that are not mentioned.

By making any designation of or reference to a particular territory or geographic area, or by using the term "country" in this document, ADB does not intend to make any judgments as to the legal or other status of any territory or area.

Open Access This work is available under the Creative Commons Attribution-NonCommercial 3.0 IGO license (CC BY-NC 3.0 IGO) http://creativecommons.org/licenses/by-nc/3.0/igo/. By using the content of this publication, you agree to be bound by the terms of this license. For attribution and permissions, please read the provisions and terms of use at https://www.adb.org/ terms-use\#openaccess.

This CC license does not apply to non-ADB copyright materials in this publication. If the material is attributed to another source, please contact the copyright owner or publisher of that source for permission to reproduce it. ADB cannot be held liable for any claims that arise as a result of your use of the material.

Please contact pubsmarketing@adb.org if you have questions or comments with respect to content, or if you wish to obtain copyright permission for your intended use that does not fall within these terms, or for permission to use the ADB logo.

Note: ADB recognizes "China" as the People's Republic of China; "Hong Kong" as Hong Kong, China; and "Vietnam" as Viet Nam.

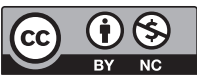

